\title{
1. Lotnisko cargo - brakujący element infrastruktury logistyki i jej ekonomiki regionu łódzkiego
}

\author{
Małgorzata Okniańska*
}

\subsection{Wstęp}

Potrzeba realizacji ambitnych zamierzeń to znak naszych czasów. Ciagły rozwój, wykonywanie skomplikowanych zadań oraz realizacja tego, co na pozór jest niewykonalne, jest zdeterminowane postępem technicznym i dążeniem do doskonałości. W dobie globalizacji, gdy świat staje się "wioska”, miliony ludzi każdego dnia przemieszczają się z jednego jego krańca na drugi. Wzmożona konsumpcja wymusza transport ogromnych ilości towarów różnego asortymentu. Aby wejść w ten spójny rytm i nadażyć za galopująca rzeczywistościa, potrzeba takich projektów, jak realizacja rozpoczętej inwestycji w postaci budowy drogi ekspresowej S8 oraz koncepcja budowy towarowego lotniska cargo w Łasku. O dojściu do skutku przedmiotowych zamierzeń może zadecydować ich odpowiednia lokalizacja, zasobne źródła finansowania, sprzyjające uwarunkowania prawne oraz determinacja ludzi.

Celem niniejszego rozdziału jest zwrócenie uwagi na realizację inwestycji bardzo istotnych z punktu widzenia rozwoju regionalnego. Potrzeba istnienia $\mathrm{w}$ naszym regionie lotniska cargo jest podyktowana jego świetna lokalizacja oraz bliskościa węzłów komunikacyjnych łaczących całą infrastrukturę. Uzupełnieniem przedsięwzięcia będzie zakończenie budowy drogi ekspresowej S8 w naszym regionie. Dzięki tej inwestycji zabezpieczone zostana potrzeby wielu firm produkcyjnych, pojawi się możliwość uzyskania i powiększenia powierzchni magazynowych, usprawnienia sieci dystrybucyjnej towarów, zwiększenia zasięgu spedycji, a także poszerzenia rynku pracy dla mieszkańców regionu.

* Mgr Małgorzata Okniańska - Katedra Logistyki, Wydział Zarządzania Uniwersytetu Łódzkiego, ul. Matejki 22/26, 90-237 Łódź. 
Pozwoli to na nieograniczony rozwój województwa łódzkiego oraz całego regionu środkowej Polski, czyniąc z naszego państwa tętniący życiem nowoczesny kraj europejski.

W rozdziale zawarto opis przedsięwzięcia w postaci projektu budowy towarowego lotniska cargo. Ważnym kryterium realizacji projektu jest aspekt współistnienia lotniska wojskowego i cywilnego. Bliskość obiektów magazynowych oraz budowa centrów logistycznych to przyszłość regionu, zakładająca wykorzystanie transportu drogowego, kolejowego i lotniczego. Garść niezbędnych faktów ukazuje obecną egzystencję 32 Bazy Lotnictwa Taktycznego w Łasku, która stanowi swoistego rodzaju wizytówkę miasta.

Podstawę opracowania stanowi przede wszystkim analiza rozmów przeprowadzonych z przedstawicielami omawianych projektów oraz władz samorządu terytorialnego. Pokazano, jak potrzebna, a wręcz konieczna dla rozwoju regionu jest budowa towarowego lotniska oraz jak najszybsza realizacja zakrojonych na szeroką skalę inwestycji drogowych. Mimo niesprzyjającej koniunktury i zawirowań w gospodarce światowej, warto sprostać temu trudnemu zadaniu.

\subsection{Charakterystyka regionu środkowej Polski w ujęciu historycznym}

Ze względu na dużą różnorodność poszczególnych obszarów Polska została podzielona na kilka regionów geograficznych. Odmienność krajobrazu, uwarunkowania pogodowe, położenie i usytuowanie głównych szlaków komunikacyjnych niejednokrotnie decyduja o atrakcyjności danego obszaru względem innych. Dodatkowo różnorodność śladów kultury materialnej i duchowej na przestrzeni wieków miała niebagatelny wpływ na ukształtowanie cywilizacji przemysłowej, układ urbanistyczny tworzonych miast, a także stosunki ludnościowe w danym regionie.

Dla lepszego przybliżenia uwarunkowań geograficznych i historycznych należy cofnąć się w czasie, by móc przeanalizować złożoność procesów, które w rezultacie ukształtowały współczesny nam obraz regionu środkowej Polski, województwa łódzkiego i miasta Łask.

Obecna rzeźba terenu zawdzięcza swe ukształtowanie skomplikowanym procesom geologicznym, które na przestrzeni ostatnich $65 \mathrm{mln}$ lat zachodziły na całym kontynencie europejskim. Procesy te, przebiegające zarówno wewnątrz, jak i na zewnątrz skorupy ziemskiej, skutkujace wzajemnym ułożeniem skał o różnym wieku i niejednakowej od- 
porności na działanie czynników atmosferycznych, miały niebagatelny wpływ na ukształtowanie oraz urozmaicenie powierzchni naszego państwa. Polska jest krajem wybitnie nizinnym. Jej północna i środkowa część, stanowiące trzy czwarte jej powierzchni, swój nizinny charakter zawdzięczaja głównie zlodowaceniom plejstoceńskim. Epoka ta, słusznie zwana lodowcowa, swą nazwę otrzymała od gigantycznych kontynentalnych lodowców, które w ówczesnym okresie pokrywały nie tylko Polskę, ale także niemal całą Europę Środkową, Azję i Amerykę Północna ${ }^{1}$. Transgresja lodowców powodująca pofałdowania gleby, tworzenie się niewielkich pagórków morenowych, rozległych terenów z przewaga szerokich i płaskich dolin, a także piaszczystych równin z niezbyt rozwiniętą siecią rzeczną i niemalże zupełnym brakiem jezior, determinowała wygląd dzisiejszego regionu środkowej Polski . "Na całokształt środowiska przyrodniczego województwa rzutuje jego położenie na pograniczu dwóch prowincji: Niżu Środkowoeuropejskiego i Wyżyn Polskich. Część północną i środkową województwa stanowia płaskie tereny silnie denudowanych równin, część południowa natomiast - pagórkowate tereny wysoczyznowe" ${ }^{\prime \prime}$. Dzięki tym uwarunkowaniom w regionie łódzkim występuje klimat przejściowy. Wpływa na niego strefa klimatów kształtujących się pod wpływem Bałtyku od północy oraz strefa klimatów ukształtowanych pod wpływem gór i wyżyn od strony południowej4. "Województwo łódzkie położone jest w centralnej części obszaru Polski, zajmuje powierzchnię $18219 \mathrm{~km}^{2}$, co stanowi 5,9\% powierzchni kraju [...], graniczy z 6 województwami oraz historycznie ukształtowanymi regionami: Mazowszem, Małopolską i Wielkopolską"5.

$Z$ punktu widzenia rozwoju gospodarczego takie centralne położenie ma ogromne znaczenie. Środkowa Polska, a w szczególności obszar obecnego województwa łódzkiego, to znany już od ponad dwustu lat prężny ośrodek przemysłowy. Na ukształtowanie się podstawowej gałęzi przemysłu tego regionu, tj. tkactwa, sukiennictwa i przędzalnictwa, miała wpływ rewolucja przemysłowa, która w krajach Europy Zachod-

${ }^{1}$ www.erygeologiczne.rumburak.us/plejstocen [z dn. 26.11.2012].

2 Encyklopedia Powszechna, wyd. II, PWN, Warszawa 1995, t. 3, s. 600.

3Synteza "Planu zagospodarowania przestrzennego województwa łódzkiego", za: uchwała nr XLV/524/2002 Sejmiku Województwa Łódzkiego z dnia 9 lipca 2002 r. w sprawie uchwalenia "Planu zagospodarowania przestrzennego województwa łódzkiego", Dz. Urz. Woj. Łódzkiego nr 249, poz. 3166 z dn. 10 października 2002 r.

${ }^{4}$ Program Ochrony Środowiska Województwa Łódzkiego na lata 2008-2011 z perspektywą na lata 2012-2015, Zarząd Województwa Łódzkiego, Łódź, marzec-lipiec 2007, Cz. I, s. 16.

${ }^{5}$ Tamże, s. 15. 


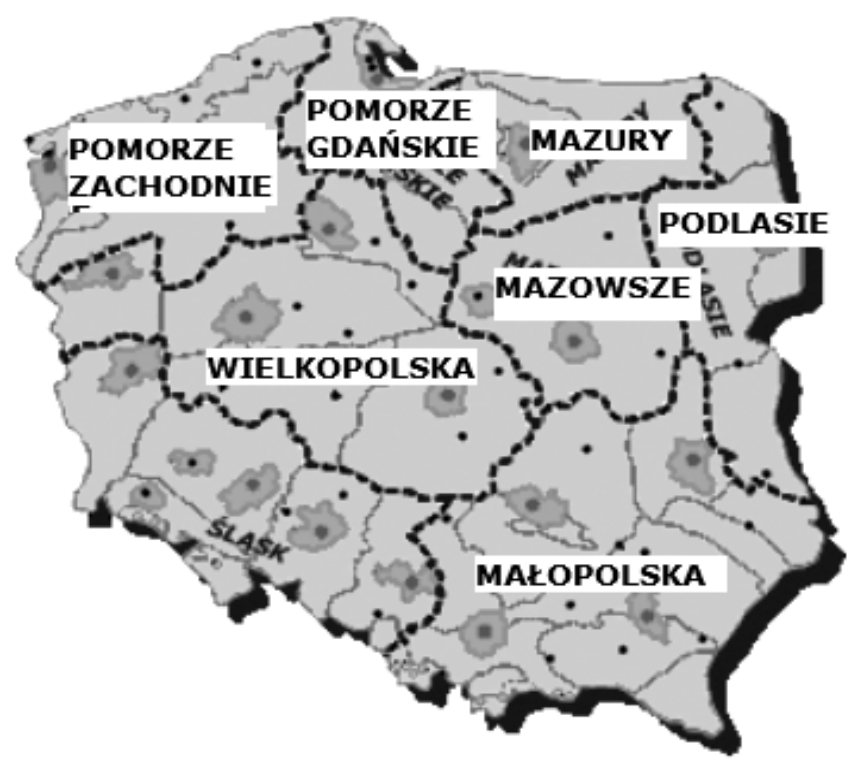

Mapa 1. Regiony etnograficzne

Źródło: opracowanie - Anna Zmysłowska

niej rozpoczęła się pod koniec XVIII w. Chałupnictwo i manufaktura, które do tej pory były źródłem zaspokajania potrzeb konsumpcyjnych społeczeństwa, powoli stawały się niewystarczajace. Wpłynęło to na proces poszukiwania nowych rozwiązań technologicznych, dzięki którym nastapiło zwiększenie wydajności pracy. Dotychczasową siłę ludzkich mięśni zastapiły maszyny zdolne do ciągłej, nieprzerwanej pracy. Prawdziwa rewolucja w przędzalnictwie dokonała się po wynalezieniu maszyny, której napęd mechaniczny stanowiło koło wodne. Kolejnym krokiem było zastosowanie silnika parowego Watta, a po opracowaniu krosna mechanicznego wydajność w tkactwie zwiększyła się 40-krotnie. Wraz z rozwojem włókiennictwa obserwuje się jednoczesny wzrost znaczenia innych gałęzi przemysłu, takich jak metalurgia, górnictwo i hutnictwo. Wszystkie te zjawiska sprzyjały zakrojonej na szeroką skalę migracji ludności ze wsi do rozwijających się miast. Wschodzący kapitalizm powodował pojawienie się nowych klas społecznych - burżuazji i proletariatu. Rozwój wielkich aglomeracji miejskich, tworzące się nowe systemy pracy, powstanie państwa obywatelskiego - to zjawiska, które nakładały się na siebie i warunkowały postęp w czasach rewolucji przemysłowej ${ }^{6}$.

\footnotetext{
${ }^{6}$ Opracowanie własne na podstawie materiałów dydaktycznych dr A. Sołtys.
} 
Na terenie naszego kraju, a zwłaszcza obecnego województwa łódzkiego rozwój przemysłu dał się zauważyć dopiero w drugiej połowie XIX w. - uprzemysłowienie postępowało nieco wolniej, nie odgrywając decydującej roli. W Łodzi rozwój włókiennictwa i tkactwa przypadł na przełom XIX i XX w. Zajmowano się tutaj przede wszystkim produkcja tkanin, a przemysł włókienniczy i sukienniczy skupiony był z reguły $w$ rękach niemieckojęzycznych tkaczy przybywających do Łodzi z Wielkopolski, Śląska i Saksonii, a także Brandenburgii, które to regiony w ówczesnym okresie były dotknięte kryzysem gospodarczym? ${ }^{7}$. Łódź na skutek postępującego procesu industrializacji powoli stawała się miastem przemysłowym, z ciągle rosnąca liczba fabryk i rozwijających się w zawrotnym tempie przedsiębiorstw tkackich. Na skalę masową budowano zakłady przemysłu włókienniczego, wokół których powstawały także osiedla mieszkaniowe. Nie bez znaczenia był fakt, że Łódź miała szczęście do światłych obywateli. Na szczególną uwagę zasługuje postać Rajmunda Rembielińskiego, który jako prezes Komisji Województwa Mazowieckiego dostrzegł w niewielkim wówczas miasteczku doskonałe warunki do stworzenia osady przemysłowej ${ }^{8}$. Jest autorem „Instrukcji prezesa Komisji Województwa Mazowieckiego Rajmunda Rembielińskiego dla geometry Filipa Viebiga w sprawie dokonania regulacji Osady Sukienniczej w Łodzi w związku z osiedlaniem się w niej sukienników", w której wyznaczył lokalizację przyszłej osady tkackiej, zaprojektował miasto wedle klasycystycznych zasad i założeń urbanistycznych, a samym osadnikom zaoferował niższe podatki i działki na obrzeżach miasta, co sprzyjało szybkiej ekspansji i niepohamowanemu rozwojowi Łodzi.

To Rajmundowi Rembielińskiemu dzisiejsza Łódź zawdzięcza pl. Wolności, czworokąt ulic Piotrkowskiej, Wschodniej, Północnej i Dzielnej', które stanowiły zaczyn przyszłego miasta. Dzięki Rembielińskiemu na terenie obecnej Łodzi znajduje się tak wiele zieleni miejskiej. W swej instrukcji prezes Komisji Województwa Mazowieckiego pisał: „Do każdego placu miejskiego nowej osady maja być domierzone takiej rozciagłości ogrody"10. Zarządzeniem Rembielińskiego utworzono w Łodzi

${ }^{7}$ www.portalwiedzy.onet.pl [z dn. 26.11.2012].

8 http://onet.pl/znany-zapomniany-obywatel-Rajmund-Rembielinski [z dn. 26.11.2012].

${ }^{9} \mathrm{Ul}$. Dzielna obecnie nosi nazwę ul. Narutowicza, za: http://onet.pl/znany-zapomniany-obywatel-Rajmund-Rembielinski [z dn. 27.07.2011].

${ }^{10}$ Instrukcja prezesa Komisji Województwa Mazowieckiego Rajmunda Rembielińskiego dla geometry Filipa Viebiga w sprawie regulacji Osady Sukienniczej w Łodzi w związku z osiedlaniem się w niej sukienników, Łódź, 12 czerwca 1823 r., za: Archiwum Państwowe w Łodzi, Akta miasta Łodzi, sygn. 536, s. 31-35. 


\section{PIALIY MIASTA HDDZII}

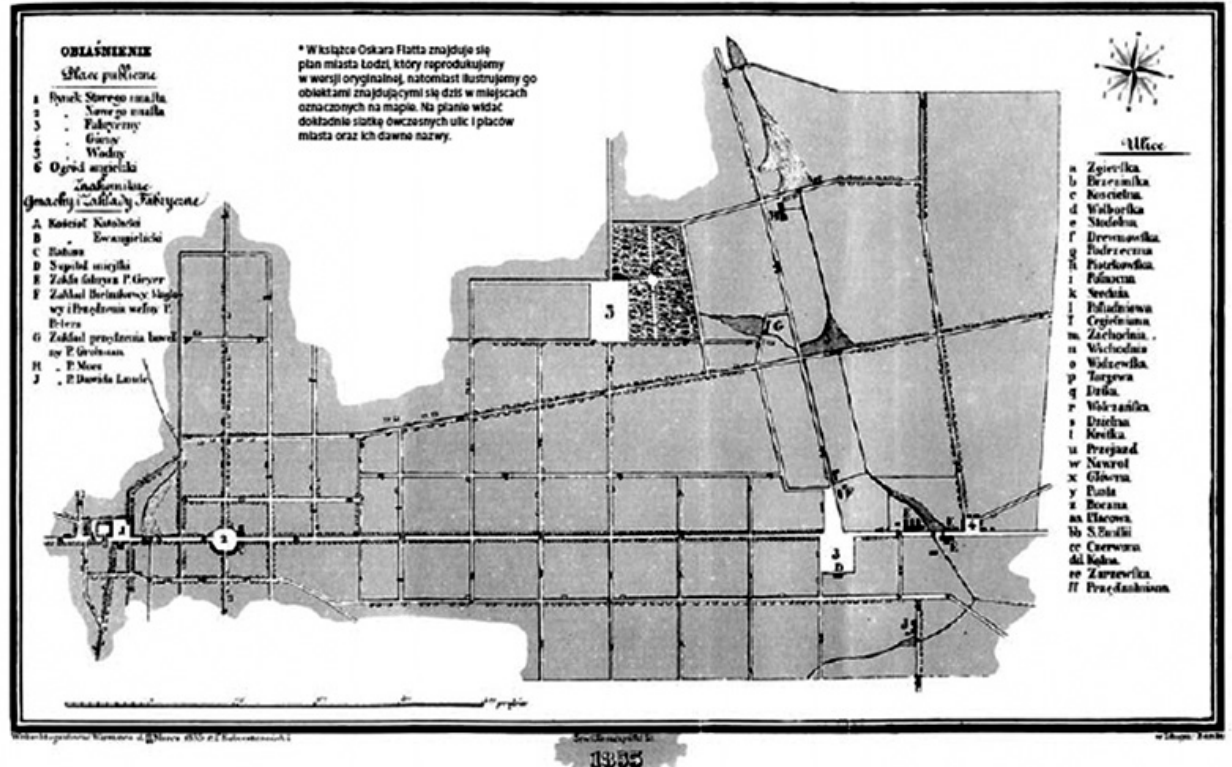

Mapa 2. Plan miasta Łodzi według Oskara Flatta - 1855 r.

Źródło: Ilustrowana encyklopedia historii Łodzi, suplement historyczny miesięcznika „Piotrkowska 104”, Urząd Miasta Łodzi, 2009, z. 4, s. 106-107

pierwsze szkółki drzewek - bardzo modnych wówczas topoli włoskich - dzięki czemu ul. Piotrkowska, stanowiąca główną arterię miasta, zazieleniła się 4 tys. drzewek ${ }^{11}$. Rajmund Rembieliński okazał się również wytrawnym przedsiębiorca i dalekosiężnym wizjonerem. Jego zasługa było sprowadzenie do Łodzi Ludwika Geyera, który był jednym z pionierów rozwoju przemysłu włókienniczego w naszym regionie, oraz Karola F. Wendischa - wybitnego specjalisty z zakresu przędzalnictwa. Rajmund Rembieliński zapisał się w historii jako „człowiek niezwykle kompetentny, skuteczny i bezinteresowny"12. Zwany był "budowniczym Łodzi przemysłowej"13. Wszystkie jego działania skupione były na polepszeniu sytuacji gospodarczej regionu i nieustannym rozwoju łódzkiego grodu, którego wyroby sukiennicze słynęły coraz bardziej na wielu rynkach europejskich.

${ }^{11}$ Ilustrowana encyklopedia historii Łodzi, suplement historyczny miesięcznika „Piotrkowska 104", Urząd Miasta Łodzi, 2009, z. 4, s. 23.

12 http://onet.pl/znany-zapomniany-obywatel-Rajmund-Rembielinski [z dn. 27.07.2011].

${ }^{13}$ Ilustrowana encyklopedia..., z. 3, s. 12. 
Łódź przełomu XIX i XX w. to miasto już w pełni uprzemysłowione, przeżywające najlepsze lata swojego rozkwitu: „w latach 1880-1913 duże fabryki łódzkie $w$ ramach koncentracji kapitału przekształciły się w spółki akcyjne, a wartość produkcji łódzkiego przemysłu włókienniczego wyniosła ponad $102 \mathrm{mln}$ rubli, co stanowiło niemal jedna czwarta część wartości całej produkcji przemysłowej Królestwa Polskiego"14. Skalę urbanizacji i uprzemysłowienia uzmysławia obraz ówczesnego centrum Łodzi, w której znajdowało się około 90 przedsiębiorstw przemysłowych, dających pracę tysiącom robotników. Wzdłuż ul. Piotrkowskiej usytuowano zakłady przemysłowe, w których produkowano różnego rodzaju wyroby włókiennicze, tkackie i przędzalnicze. W tab. 1 przedstawiono zestawienie niektórych, wybranych zakładów oraz fabryk, nazwisk właścicieli i ówczesnych adresów ich siedzib. Głównym produktem wytwórczym tych przedsiębiorstw były różnego rodzaju tkaniny, sukna, wstążki, materiały, przędza, a także serwety i koronki.

Analizując tab. 1, mimo iż umiejscowiono w niej wybrane przedsiębiorstwa, można zauważyć duże skupienie i zagęszczenie zakładów oraz fabryk - wskazuja na to kolejne numery sąsiadujących ze sobą posesji. Główne centrum fabryczne stanowiła ul. Piotrkowska, wzdłuż której budowano zarówno zakłady pracy, jak i mieszkania dla pracujących w nich robotników. Ponadto $w$ tabeli zwraca uwagę różnorodność asortymentu, zaawansowanie technologiczne i techniczne, a także zapewne bogate wzornictwo łódzkich wyrobów włókienniczych, co w ówczesnym czasie miało duże znaczenie ze względu na kierunek eksportu - głównymi rynkami zbytu był bardzo chłonny rynek rosyjski i wymagający rynek dalekowschodni. Ówczesna oferta produktów bawełnianych obejmowała m.in. takie tkaniny, jak muślin, pika, ryps, kortum, perkal ${ }^{15}$. Znamienny jest fakt skupienia własności kapitałowej i przemysłowej w rękach właścicieli zagranicznych, obcojęzycznych, z przewaga fabrykantów żydowskich. Rozwijający się kapitalizm wyznaczał twarde reguły rynkowej rzeczywistości. Pierwsi przybywający fabrykanci obcego pochodzenia nie mieli w "ziemi obiecanej" łatwego startu. Często spotykało ich bankructwo lub upaństwowienie za długi, niespłacone pożyczki czy nieuiszczone podatki ${ }^{16}$. Mimo wielu przeszkód z biegiem czasu przybywało przedsiębiorców, którzy na fali sprzyjającej koniunktury potrafili stworzyć niemal imperia fabryczne. Budowano nie tylko obiekty, w których produkowano szeroki asortyment towarów bawełnianych, lecz tak-

\footnotetext{
14 Tamże, z. 7, s. 206.

15 Tamże, z. 4, s. 97.

16 Tamże, z. 4, s. 96.
} 
Tabela 1. Wykaz wybranych przedsiębiorstw branży tekstylnej funkcjonujących na terenie Łodzi

\begin{tabular}{|c|c|c|c|}
\hline Lp. & Nazwa przedsiębiorstwa & Właściciel & Adres \\
\hline 1. & Tkalnia parowa wyrobów wełnianych & Gustaw Lorenc & Piotrkowska 57 \\
\hline 2. & $\begin{array}{l}\text { Tkalnia i apretura wyrobów } \\
\text { wełnianych }\end{array}$ & Gustaw Wertszycki & Piotrkowska 75 \\
\hline 3. & Fabryka kortów i sukna & Hugon Wulfsohn & Piotrkowska 78 \\
\hline 4. & Tkalnia serwet i kortów & Teodor Steigert & Piotrkowska 90 \\
\hline 5. & $\begin{array}{l}\text { Fabryka wstążek jedwabnych, } \\
\text { półjedwabnych i tasiemek }\end{array}$ & Samuel Czamański & Piotrkowska 96 \\
\hline 6. & Tkalnia wyrobów wełnianych & Juliusz Heinzl & Piotrkowska 104 \\
\hline 7. & $\begin{array}{l}\text { Tkalnia i przędzalnia wyrobów } \\
\text { wełnianych }\end{array}$ & Karol Bennich & Piotrkowska 105 \\
\hline 8. & Apretura wyrobów wełnianych & Franciszek Fischer & Piotrkowska 112 \\
\hline 9. & $\begin{array}{l}\text { Fabryka materiałów meblowych } \\
\text { i apretura }\end{array}$ & Jan Fijal & Piotrkowska 127 \\
\hline 10. & Tkalnia kortów & Karol Eisert & Piotrkowska 135 \\
\hline 11. & $\begin{array}{l}\text { Tkalnia i przędzalnia wyrobów } \\
\text { bawełnianych }\end{array}$ & $\begin{array}{l}\text { Franciszek } \\
\text { Ramisch }\end{array}$ & Piotrkowska 140 \\
\hline 12. & $\begin{array}{l}\text { Tkalnia i przędzalnia wyrobów } \\
\text { bawełnianych }\end{array}$ & Gotfryd Steigert & Piotrkowska 159 \\
\hline 13. & $\begin{array}{l}\text { Tkalnia, blich i drukarnia wyrobów } \\
\text { bawełnianych }\end{array}$ & Karol Hoffrichter & Piotrkowska 204 \\
\hline 14. & $\begin{array}{l}\text { Farbiarnia i apretura wyrobów } \\
\text { wełnianych }\end{array}$ & $\begin{array}{l}\text { Aleksander } \\
\text { Skrudziński }\end{array}$ & $\begin{array}{l}\text { Piotrkowska } \\
212 / 214\end{array}$ \\
\hline 15. & Fabryka koronek & Gustaw Geyer & Piotrkowska 278 \\
\hline
\end{tabular}

Źródło: Ilustrowana encyklopedia historii Łodzi, suplement historyczny miesięcznika „Piotrkowska 104", Urząd Miasta Łodzi, 2009, z. 7, s. 207-208.

że budynki nierozerwalnie związane z ówczesnym procesem produkcji - przędzalnie, farbiarnie, drukarnie tkanin, suszarnie i płuczkarnie oraz budynki gospodarcze przeznaczone m.in. na stajnie i wozownie. Fabrykanci łódzcy dostawali pozwolenia na budowę obiektów mieszkalnych dla robotników, sprowadzając niekiedy z innych regionów całe rodziny wykwalifikowanych tkaczy-rękodzielników.

Można wysnuć wniosek, że ostatnie dekady XIX w. to okres intensywnego rozwoju i rozbudowy przemysłu włókienniczego. Nowoczesne fabryki z charakterystycznymi wysokimi, dymiącymi kominami z bie- 


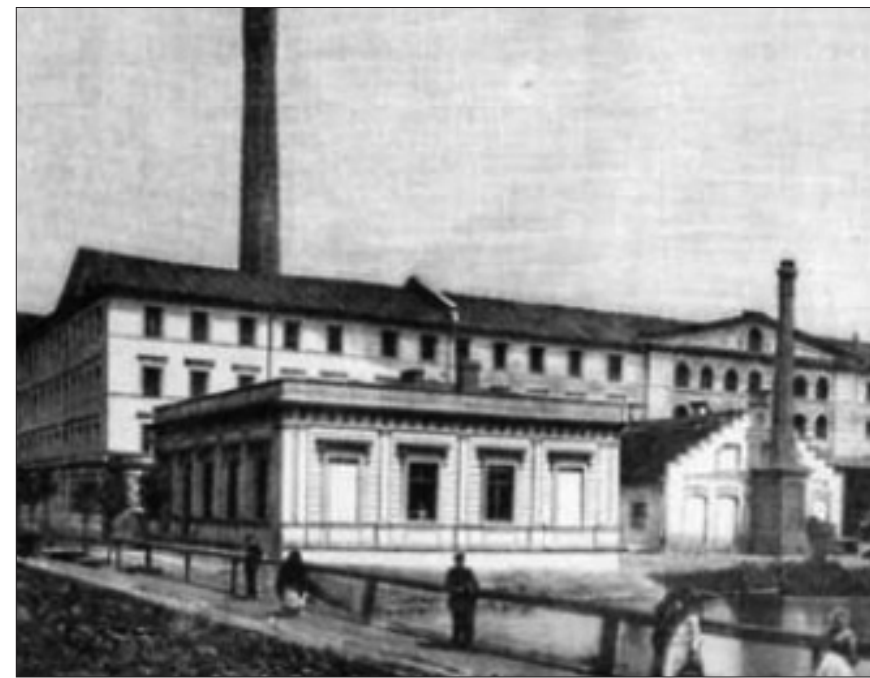

Zdjęcie 1. Charakterystyczny obraz zabudowy fabrycznej w XIX w. - Biała Fabryka Ludwika Geyera

Źródło: Ilustrowana encyklopedia historii Łodzi, suplement historyczny miesięcznika "Piotrkowska 104", Urząd Miasta Łodzi, 2009 , z. 4, s. 120

giem czasu stały się nieodłączną wizytówką krajobrazu uprzemysłowionej Łodzi.

Aby całkowicie dopełnić obrazu warunków, które miały wpływ na ówczesny wizerunek Łodzi, należy koniecznie wspomnieć o uwarunkowaniach polityczno-gospodarczych i demograficznych w tamtym okresie. Z periodyzacji dziejów miasta Łodzi można dowiedzieć się, że w latach 1793-1816 Łódź znajdowała się pod zaborem pruskim, a po sekularyzacji dóbr kościelnych, od 1806 r. przestała stopniowo podlegać jurysdykcji biskupiej, przechodząc w posiadanie rządu pruskiego i stając się miastem rządowym ${ }^{17}$.

Na mocy traktatu rozbiorowego od stycznia 1793 r. obszar województw sieradzkiego i łęczyckiego znalazł się pod panowaniem Prus. Tereny te zostały wcielone do departamentu warszawskiego, na którego czele stał minister Bucholtz. Od tego momentu władze pruskie zaczęły wprowadzać nowy podział administracyjno-terytorialny. Niemal cały obszar miasta Łodzi znalazł się w nowo utworzonym powiecie zgierskim, a tylko południowe peryferie miasta swym zasięgiem obejmował powiat szadkowski.

17 Tamże, z. 3, s. 63. 


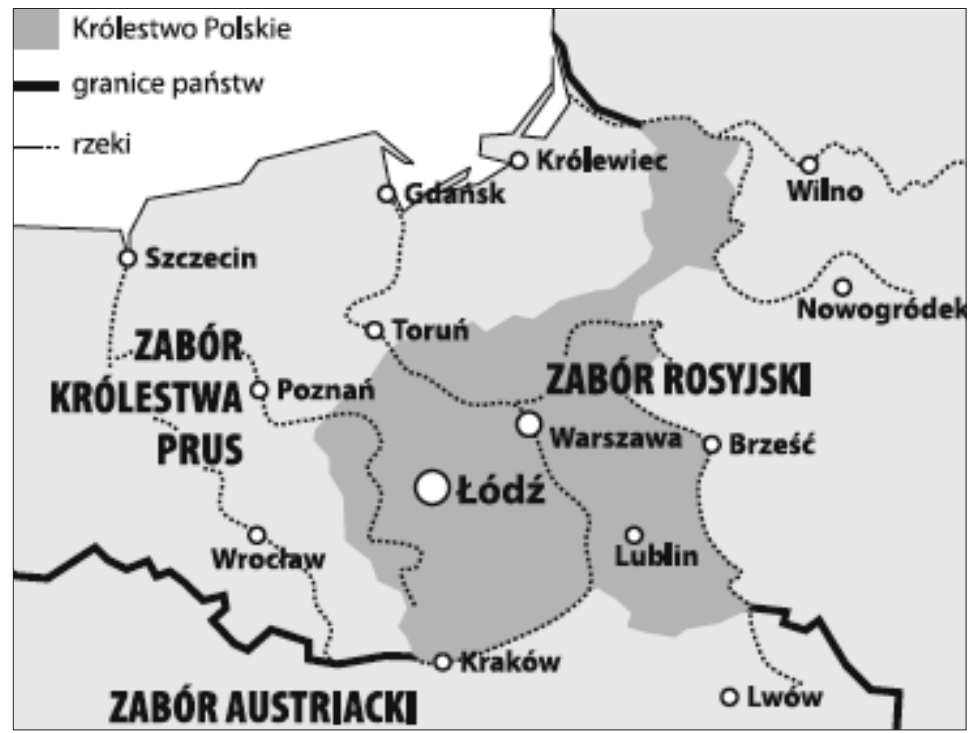

Mapa 3. Podział administracyjno-terytorialny w czasach rozbiorów Polski Źródło: jak do mapy 2, z. 3, s. 9

Taki podział terytorialny nie został zmieniony również w czasach Księstwa Warszawskiego, w którego granicach Łódź znajdowała się do roku $1815^{18}$. Wówczas weszła w skład Królestwa Polskiego. Na długo przed procesem industrializacji Łodzi, mimo różnorakich perturbacji i zawirowań historycznych, na terenach podłódzkich wsi widać było ożywienie gospodarcze związane z handlem drewnem, które pozyskiwano w okolicznych rozległych lasach. Ówczesny rozwój gospodarczy związany był również z koniunkturą na szkło produkowane w rozwijających się w coraz większym tempie hutach. Jednocześnie na tereny łódzkie zaczęła napływać fala osadników przybywających z różnych stron Europy, a w szczególności z ziem niemieckich i holenderskich, co dodatkowo pobudzało rozwój gospodarczy i stanowiło zalążek procesu uprzemysłowienia regionu łódzkiego. Proces ten miał ścisły związek z migracja ludności „za chlebem”, co było efektem coraz bardziej zauważalnych skutków rewolucji przemysłowej, wkraczającej również do Polski.

Zaludnienie miasta i terenów łódzkich w końcu XVIII i na początku XIX w. nie było duże. W pierwszym wydaniu książki Oskara Flatta, która ukazała się nakładem "Gazety Polskiej" w Warszawie pt. Opis miasta Łodzi pod względem historycznym, statystycznym i przemysłowym,

18 Tamże, z. 3, s. 64. 
można było zobaczyć pierwszy plan Łodzi oraz przeczytać: „Miasto, zostajace w posiadaniu Rybickiego, Arcybiskupa Kujawskiego, liczyło mieszkańców ogółem 190, w tej liczbie mężczyzn 89, kobiet 90, Żydów 11 ; kościół był jeden katolicki, dymów było 44, domów niezamieszkałych 11 , placów pustych 18 , stodół 44 . Z zabudowań publicznych istniał tylko jeden drewniany areszt policyjny, i to w stanie jak najgorszym; studzien wykazano 4 publiczne i 4 prywatne, jeden młyn wodny, oraz szynków dwa: jeden dominialny, drugi probostwa. Nie zapomniano w lustracyi i o inwentarzu. [...] miało miasto dwóch garbarzy, jednego ślusarza, jednego krawca, zdaniem lustratorów skromna ta ludność rzemieślnicza, aż nadto dla potrzeb miejskich była wystarczająca"19.

\begin{tabular}{|c|}
\hline 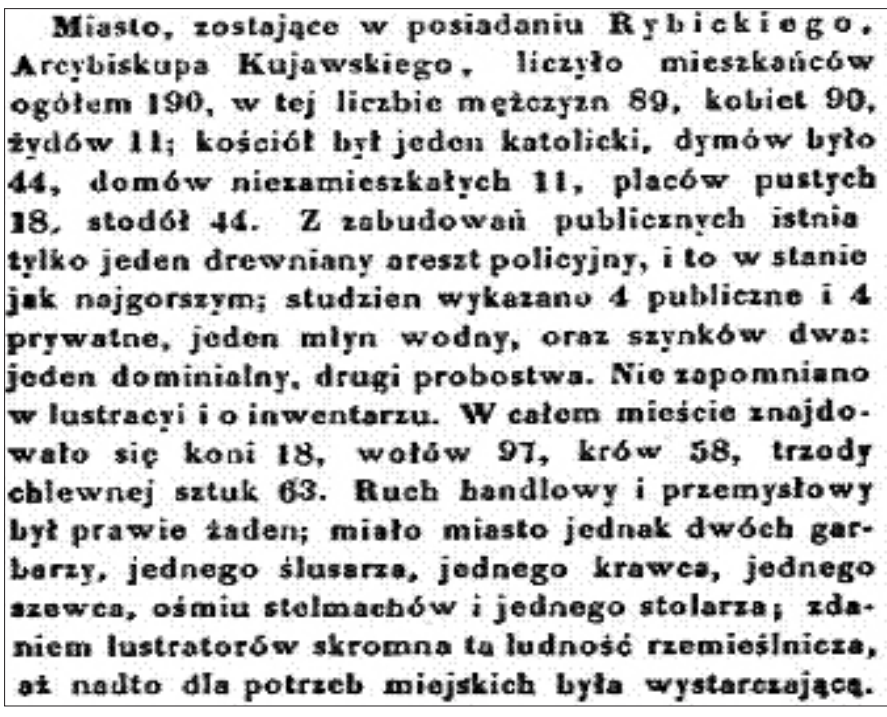 \\
\hline
\end{tabular}

Zdjęcie 2. Oryginał tekstu Oskara Flatta z 1853 r.

Źródło: jak do zdjęcia 1, z. 3, s. 64

Przytoczony tekst opisuje rzeczywistość z końca XVIII w., jednak z biegiem czasu, wraz ze wzmożoną fala osadnictwa na terenach łódzkich, zmieniały się w szybkim tempie również uwarunkowania demograficzne. W czasach, gdy swą działalność rozwijał Rajmund Rembieliński, to jest około roku 1820, w Łodzi mieszkało już blisko 800 obywateli. Rok 1820 jest przez historyków uważany za początek nowej Łodzi przemysłowej. Żywiołowy wizjoner Rembieliński z wielkim rozmachem, a przede wszystkim skutecznie, w szczytowym okresie swej działalności

19 O. Flatt, Opis miasta Łodzi pod względem historycznym, statystycznym i przemysłowym, Warszawa 1853, za: Ilustrowana encyklopedia..., z. 3, s. 63. 
zapoczątkował proces gospodarczego rozkwitu miasta, które otrzymało szansę na zmianę feudalnego dotąd charakteru. Warunki ludnościowe w mieście ulegały przeobrażeniom niemal z roku na rok. Rezultatem kolejnych zmian terytorialnych w 1825 r. było powiększenie terenu miasta o tzw. osadę prządków. Przyległe obszary dotychczasowych folwarków, wsi i lasów zaczęto inkorporować20 jako tereny miejskie. Pięć lat później, gdy nowa osada sukiennicza działała już pełna para, a osadnicy z Niemiec, Czech, Ślaska i Wielkopolski stanowili spory odsetek ludności, Łódź liczyła około 5 tys. mieszkańców. W roku 1840, dzięki zatwierdzeniu przez Komisję Rządową Spraw Wewnętrznych i Policji ${ }^{21}$ projektu włączenia do Łodzi terenów m.in. leśnictwa Pabianice, liczba mieszkańców stale rosła, by osiagnać w 1857 r. 27890 mieszkańców stałych $^{22}$. Stopniowo do terenów miejskich dołączano kolejne przyległe osady - Dąbrowę, Janów, Chojny, Stoki, Doły, Antoniew, Olechów. Niegdyś stanowiły one obszar słabo zaludnionych osiedli, w dużym stopniu zalesionych, jednakże będących doskonałym zapleczem do pozyskania nowych terenów miejskich, co sprzyjało procesowi urbanizacji i industrializacji ówczesnego ośrodka przemysłowego. Dziś nazwy te określaja autonomiczne dzielnice Łodzi.

Kolejne burzliwe lata zmieniającej się rzeczywistości dziejowej wycisnęły piętno na charakterze Łodzi. „Wraz z tworzeniem organizmu miejskiego zaczęły powstawać $\mathrm{w}$ Łodzi różnego typu nowe instytucje, obiekty użyteczności publicznej, urządzenia komunalne"23. Pierwsze apteki, szpitale, jarmarki, pierwsza komunikacja miejska, a nawet oświetlenie miejskie, studnie publiczne, a niedługo potem wodociąg wszystko to Łódź zawdzięcza sprzyjającej koniunkturze na bawełnę, przychylności władz i przedsiębiorczości ówczesnych obywateli.

Ciagła transformacja życia społecznego, gospodarczego i politycznego, a także zmieniajace się stosunki ludnościowe są znamienna cechą rozwijających się społeczeństw. Przez kolejne lata, mimo ciągłych wahań koniunktury, łódzki ośrodek przemysłowy funkcjonował w rynkowej rzeczywistości, dynamicznie rozwijając infrastrukturę miejską, której zadaniem było zaspokojenie potrzeb 300-tysięcznej wówczas ludności. Ożywienie gospodarcze niosło się na wszystkie przyległe obszary, położone bliżej lub dalej od Łodzi, sprzyjając również rozwojowi całego regionu. Rozkwitały okoliczne miasteczka - Nowosolna,

\footnotetext{
${ }^{20}$ Ilustrowana encyklopedia..., z. 8, s. 217.

${ }^{21}$ Tamże, z. 3, s. 72.

22 http://pl.wikipedia.org/wiki/Kalendarium_historii_\%C5\%81odzi [z dn. 26.11.2012].

${ }^{23}$ Ilustrowana encyklopedia..., z. 4, s. 28.
} 
Zgierz, Konstantynów, Pabianice. Motorem ich rozwoju była bliskość Łodzi przemysłowej.

Trzeba pamiętać też o burzach dziejowych, jakimi targana była w tym czasie cała Rzeczypospolita. Nasilające się ruchy robotnicze pojawiające się na fali europejskich ruchów rewolucyjnych, powstania listopadowe i styczniowe, a nawet rewolucja 1905 r. wywarły wpływ na Łódź fabrykantów i milionerów. Do głosu dochodziły masy robotnicze, które wyzyskiwane przez właścicieli fabryk coraz bardziej odczuwały skutki uciążliwego systemu pracy. Mimo to tradycje włókiennicze w regionie łódzkim kontynuowane były w okresie międzywojennym, a także w Polsce powojennej. Niewątpliwie włókiennictwo stanowiące swoistą monokulturę, jako dziedzina przemysłu zawsze kojarzyć się będzie z regionem łódzkim. Dzięki temu również pokrewne gałęzie przemysłu, pełniące niejako rolę wspomagająca, miały szansę rozwinąć się i funkcjonować nawet w socjalistycznej rzeczywistości XX w. Natomiast czasy obecne są przykładem niebywałej transformacji w różnych obszarach życia społecznego.

\subsection{Koncepcja funkcjonalno-przestrzenna województwa łódzkiego}

Z upływem lat wszystkie obszary życia społecznego i publicznego ulegaja ciagłej transformacji. Zmianom podlegają nie tylko miasta czy regiony, lecz niekiedy także forma instytucjonalna państwa.

Nowa reforma administracyjna, która weszła w życie 1 stycznia 1999 r., wprowadziła wiele istotnych zmian w dotychczasowym podziale terytorialnym naszego kraju. Podstawy funkcjonowania organów państwa w związku z wdrożeniem wspomnianej reformy można znaleźć w kilku aktach prawnych. Jednym z nich jest ustawa o wprowadzeniu zasadniczego trójstopniowego podziału terytorialnego państwa ${ }^{24}$. $\mathrm{Na}$ mocy ustawy, której celem było utworzenie większych regionów mogacych skutecznie konkurować z regionami europejskimi, wprowadzono 16 województw podzielonych na mniejsze jednostki administracyjne, czyli powiaty ${ }^{25}$ i gminy ${ }^{26}$. Jednak najwyższym aktem prawnym mającym

${ }^{24}$ Ustawa z dn. 24 lipca 1998 r. o wprowadzeniu zasadniczego trójstopniowego podziału terytorialnego państwa, Dz.U. z 1998 r., nr 96, poz. 603 z późn. zm.

${ }^{25}$ Ustawa z dn. 5 czerwca 1998 r. o samorządzie powiatowym, Dz.U. z 2001 r., nr 142, poz. 1592 z późn. zm.

${ }^{26}$ Ustawa z dn. 8 marca 1990 r. o samorządzie gminnym, Dz.U. z 1990 r., nr 16, poz. 95 z późn. zm. 
nadrzędne znaczenie „w trosce o byt i przyszłość naszej Ojczyzny"27 jest Konstytucja RP, która określiła w sposób wyraźny pozycję ustrojowa nowych jednostek administracyjnych ${ }^{28}$ oraz ustaliła obowiąująca od tej pory zasadę decentralizacji ${ }^{29} \mathrm{w}$ odniesieniu do ustroju terytorialnego. Od tego momentu rozpoczęło się budowanie państwa polskiego od nowa. Oznaczało to, że zarówno mieszkańcy gmin, jak i powiatów "z mocy prawa tworzą wspólnotę samorządowa"30. Zainicjowany proces tworzenia nowych struktur i obszarów terytorialnych zasadniczo sprowadzał się do ustanowienia nowych granic jednostek samorządu terytorialnego i „poprawienia warunków wykonywania zadań publicznych o charakterze wojewódzkim oraz zachowania regionalnych więzi społecznych, gospodarczych i kulturowych"131.

Należy wspomnieć, że po raz pierwszy województwo łódzkie pojawiło się na mapie Polski w styczniu 1919 r. ${ }^{32}$ Po reformie administracyjnej 1999 r. znacznie zwiększyło ono swoje dotychczasowe terytorium. Obecnie "strukturę administracyjną województwa tworzą: 24 powiaty, w tym 3 grodzkie i 21 ziemskich, 177 gmin, w tym 18 miejskich, 24 miejsko-wiejskie i 135 wiejskich"33, łącząc dotąd historycznie odrębne subregiony: sieradzki, łęczycki, rawski, opoczyński i łowicki. Województwo łódzkie sąsiaduje z województwem kujawsko-pomorskim, wielkopolskim, opolskim, świętokrzyskim i mazowieckim. W regionie łódzkim funkcjonuja 42 miasta, a liczba ludności sięga 2541 832, czyli blisko $7 \%$ zaludnienia kraju ${ }^{34}$.

Poświęcając nieco uwagi zdiagnozowaniu sytuacji społeczno-gospodarczej regionu, możemy zauważyć pewne zjawiska, które rzutuja na obraz obecnego województwa łódzkiego. Struktura demograficzna, biorąc pod uwagę wiek i płeć populacji oraz poziom wykształcenia i zatrudnienia, w województwie łódzkim nie wypada korzystnie. Konsekwencją tego jest dość wysoki wskaźnik feminizacji dla naszego regionu,

${ }^{27}$ Konstytucja Rzeczypospolitej Polskiej z dn. 2 kwietnia 1997 r., Dz.U. z 1997 r., nr 78, poz. 483 z późn. zm., Preambuła.

28 Tamże, art. 16.

29 Tamże, art. 15.

30 Ustawa z dn. 5 czerwca 1998 r. o samorządzie powiatowym, rozdz. I, art. 1, pkt 1; ustawa z dn. 8 marca 1990 r. o samorządzie gminnym, rozdz. I, art. 1, pkt 1 .

31 Ustawa z dn. 24 lipca 1998 r. o wprowadzeniu zasadniczego trójstopniowego podziału terytorialnego państwa, art. 5 a.

32 Regionalny Program Operacyjny Województwa Łódzkiego na lata 2007-2013, wyd. Urząd Marszałkowski, Łódź, wrzesień 2007, s. 4.

33 Synteza "Planu zagospodarowania przestrzennego województwa łódzkiego".

${ }^{34}$ Regionalny Program Operacyjny Województwa Łódzkiego na lata 2007-2013, s. 4. 
a także niski poziom współczynnika dynamiki demograficznej. Zjawiska te silnie oddziałuja na wiele aspektów życia publicznego i społecznego, a w szczególności gospodarczo-ekonomicznego. Wychodząc naprzeciw problemom gospodarczym, samorząd województwa łódzkiego, który odpowiada za sporządzenie i uchwalenie planu zagospodarowania przestrzennego ${ }^{35}$, umieścił te zagadnienia m.in. w ważnym dokumencie planistycznym pt. Synteza „Planu zagospodarowania przestrzennego województwa łódzkiego" ${ }^{36}$, stwierdzając: "w celu odwrócenia niekorzystnych tendencji przyjęto podstawowe działania warunkujące i motywujące zrównoważone zagospodarowanie [...] województwa łódzkiego, opierające się na realnych podstawach dynamizujących rozwój i umożliwiających sprostanie wymogom rosnącej konkurencji międzyregionalnej i globalnej"37. Władze województwa widzą zatem potrzebę szybkiego działania na rzecz rozwoju gospodarczego regionu tódzkiego poprzez aktywizację biernych dotąd obszarów, realizację strategicznych celów w postaci podniesienia konkurencyjności oraz wyznaczenie priorytetowych sfer działania skupionych na poprawie warunków życia ludności. Takie postępowanie zgodne jest z istota Strategii Rozwoju Województwa Łódzkiego ${ }^{38}$, która precyzując tok postępowania, określa „politykę władz [...] i koncepcję świadomego i systemowego sterowania długookresowym rozwojem regionu"39.

Liczne opracowania dla całego regionu łódzkiego ${ }^{40}$ i corocznie sporządzane zestawienia Urzędu Statystycznego, a także dokumenty rzadowe i Komisji Europejskiej w pełni uwidoczniły obraz obecnej rzeczywistości ekonomicznej, umożliwiając dogłębna analizę ilościową i jakościową zjawisk zachodzących w wielu obszarach. Włókienniczo-odzieżowy charakter województwa łódzkiego powoli odchodził w przeszłość, pozostawiając za sobą wspomnienia najlepszych czasów szczytowej prosperity. Powoli aglomeracja łódzka wraz z bliższym i dalszym otoczeniem zaczęła nabierać nowego znaczenia, stając się ośrodkiem

${ }^{35}$ Ustawa z dn. 7 lipca 1994 r. o zagospodarowaniu przestrzennym, Dz.U. z 1999 r., nr 15, poz. 139 z późn. zm.

${ }^{36}$ Synteza "Planu zagospodarowania przestrzennego województwa łódzkiego", s. 2.

37 Tamże.

38 Założenia aktualizacji strategii rozwoju województwa łódzkiego do roku 2020, Łódź, listopad 2004, s. 4.

${ }^{39}$ Strategia Rozwoju Województwa Łódzkiego na lata 2007-2020, Łódź, styczeń 2006, s. 4.

${ }^{40}$ Regionalny Program Operacyjny Województwa Łódzkiego na lata 2007-2013, rozdział 1. 
produkcji energii elektrycznej ${ }^{41}$, nowych branż przemysłowych, jak np. produkcja płytek ceramicznych, materiałów budowlanych, leków farmaceutycznych i sprzętu AGD. Priorytetowego znaczenia zaczął nabierać transport i spedycja. Wiązało się to $z$ dogodnym, centralnym położeniem województwa względem innych obszarów kraju. Tym zjawiskom niewątpliwie sprzyjało istnienie Łódzkiej Specjalnej Strefy Ekonomicznej, Kleszczowskiej Strefy Przemysłowej oraz Parku Przemysłowego Boruta-Zgierz ${ }^{42}$. Działalność stref ekonomicznych w sposób radykalny podniosła atrakcyjność regionu łódzkiego, co uwidoczniło się w zwiększeniu dynamiki eksportu nowoczesnych działów przemysłowych, sprzyjało zwiększeniu innowacyjności gospodarki regionu i podniesieniu poziomu przedsiębiorczości mieszkańców. Przez pryzmat tych działań można już było dostrzec nowy charakter regionu i kierunek określony przez dominujące na tym obszarze klastry ${ }^{43}$. Efektem takich kompleksowych działań jest np. otwarcie się na nowe dziedziny technologiczne promujące ekologiczność w gospodarce. Znawcy tematu wiedza, że pod względem wykorzystania odnawialnych źródeł energii w postaci turbin wiatrowych województwo łódzkie zajmuje trzecie miejsce w kraju, biorąc pod uwagę ogólną moc zainstalowanych urządzeńn ${ }^{44}$.

Za przemianami gospodarczymi szły zmiany w sferze społecznej i publicznej, a także funkcjonalno-przestrzennej ${ }^{45}$. Istotny wydaje się problem dostępu młodych ludzi do edukacji, a co za tym idzie, zwiększenie poziomu wykształcenia specjalistycznych kadr, szczególnie potrzebnych w okresie rozwoju gospodarczego. Niemałego znaczenia nabiera również świadomość władz samorządów terytorialnych co do konieczności korelacji planu zagospodarowania przestrzennego województwa z planami przestrzennymi lub studiami i kierunkami zagospodarowania przestrzennego poszczególnych gmin. Celem strategicznym w tym zakresie jest "zwiększenie dostępności gospodarczej regionu"46. Wykorzystujac bardzo dobre, centralne położenie województwa łódzkiego w sposób optymalny, region ma szanse ponownie przeżywać okres gospodarczej koniunktury.

${ }^{41}$ M. Łabik, Elektrownie wiatrowe - przed przystapieniem do inwestycji, "Licz i Buduj" 2011, nr 9, s. 26.

42 Strategia Rozwoju Województwa Łódzkiego na lata 2007-2020, s. 8.

${ }^{43}$ Deloitte Business Consulting S.A., Benchmarking klastrów w Polsce - 2010. Raport z badania, Polska Agencja Rozwoju Przedsiębiorczości, Warszawa 2010, s. 123.

${ }^{44}$ M. Łabik, Elektrownie wiatrowe..., s. 26.

45 Strategia Rozwoju Województwa Łódzkiego na lata 2007-2020, s. 10.

${ }^{46}$ Tamże, s. 26. 


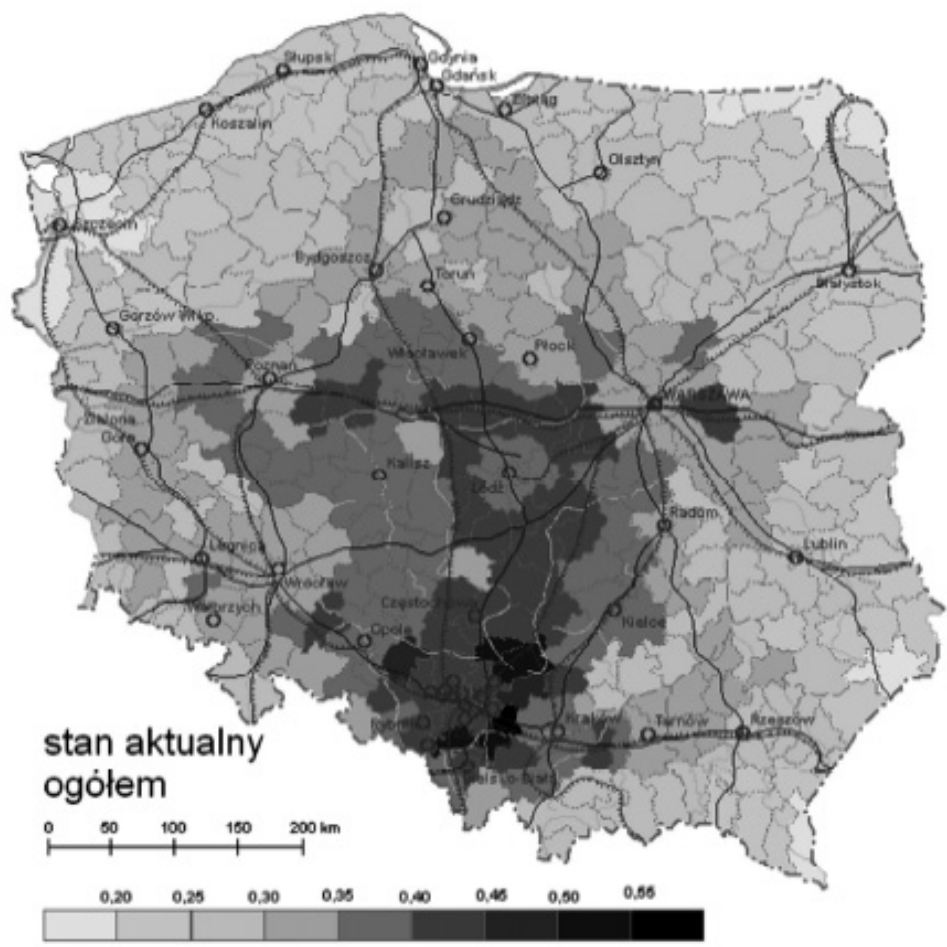

Mapa 4. Powiatowe zróżnicowanie wskaźnika dostępności kraju na 2009 r.

Źródło: T. Komornicki i in., Opracowanie metodologii liczenia wskaźnika międzygałęziowej dostępności transportowej terytorium Polski oraz jego oszacowanie, IGiPZ PAN, Warszawa 2008

Mapa 4 pokazuje stan aktualny wskaźnika dostępności ${ }^{47}$ naszego regionu $\mathrm{w}$ porównaniu $\mathrm{z}$ innymi powiatami i województwami. Na tym tle region łódzki, jak pokazuje wskaźnik oscylujacy między 0,35 a $0,50^{48}$, przedstawia się $\mathrm{w}$ bardzo korzystnym świetle. Interpretacja tego zjawiska napawa optymizmem, gdyż oznacza to, że władze terytorialne i mieszkańcy regionu maja szansę stanać przed wyzwaniem, jakie niesie obecność Polski w Unii Europejskiej. Wiaże się to m.in. z przechodzeniem od społeczeństwa przemysłowego do społeczeństwa

${ }^{47}$ Wskaźnik dostępności - wielkość, która charakteryzuje stopień dostępności do danego dobra; może być mierzona na zasadzie pomiaru bezpośredniego lub poprzez analizę badań społecznych. Ważnym elementem jest wyodrębnienie wszystkich parametrów mających wpływ na wynik i jego interpretację, za: W. Wańkowicz, Wskaźniki realizacji usług publicznych, Program Rozwoju Instytucjonalnego, MSWiA, Kraków 2004, s. 5.

${ }^{48}$ T. Komornicki i in., Opracowanie metodologii liczenia wskaźnika międzygałęziowej dostępności transportowej terytorium Polski oraz jego oszacowanie, IGiPZ PAN, Warszawa 2008 , s. 28. 
informatycznego, a także z niwelacją zaszłości poprzedniego systemu politycznego wraz z anulowaniem skutków opóźnienia cywilizacyjnego w porównaniu do innych krajów Starego Kontynentu. Wszystko to znamionuje postęp gospodarczo-kulturowy i pozwala utrzymać łączność ze światem zewnętrznym, który poprzez ciagły rozwój zagwarantuje odrębność kulturowa, a jednocześnie spójność i zbieżność interesów gospodarczych. Najlepiej uwidacznia to misja nakreślona w Strategii Rozwoju Województwa Łódzkiego, polegająca na motywowaniu i inspirowaniu do wspólnego wysiłku oraz dawaniu czytelnego komunikatu wszystkim uczestnikom i podmiotom zaangażowanym w rozwój województwa. Istota zagadnienia jest: „Podniesienie atrakcyjności województwa łódzkiego w strukturze regionalnej Polski i Europy jako regionu sprzyjającego zamieszkaniu i gospodarce przy dążeniu do budowy wewnętrznej spójności i zachowaniu różnorodności jego miejsc"49.

Aby określenie misji miało całościowy wymiar, musi dopełnić go wizja, czyli pewna koncepcja (obraz nieodległej przyszłości), która w sposób klarowny określa przy sprzyjających założeniach model danej instytucji ${ }^{50}$. W tym konkretnym przypadku "instytucja” jest całe województwo łódzkie, zaś obowiązek nadania tej koncepcji realnych ram spoczywa bezpośrednio na samorządzie województwa łódzkiego, a pośrednio także na samorządach terytorialnych i ludziach wykonujących obowiązki z tego tytułu. Kierując się nadrzędnym celem w Syntezie "Planu zagospodarowania przestrzennego województwa łódzkiego", wyznaczono horyzonty planistyczne, które korelując z Planem zagospodarowania przestrzennego województwa łódzkiego muszą również zachować spójność z głównymi celami polityki przestrzennej naszego państwa, zawartymi w Koncepcji polityki przestrzennego zagospodarowania kraju ${ }^{51}$. Należy podkreślić, że sprawa takiej rangi wymusza ciagła, systematyczną współpracę, wymianę informacji i doświadczeń na różnych poziomach władzy terytorialnej - zarówno wojewódzkiej, powiatowej, jak i gminnej. Przedmiotowe horyzonty planistyczne opracowane dla regionu łódzkiego zawieraja się $w$ trzech okresach czasowych:

1. Perspektywa bliższa - obejmująca okres do 2006 r., kiedy to następowała praca na rzecz promowania zagadnień zbieżnych z pro-

\footnotetext{
${ }^{49}$ Strategia Rozwoju Województwa Łódzkiego na lata 2007-2020, s. 10.

${ }^{50}$ K. Obłój, Strategia organizacji. W poszukiwaniu trwałej przewagi konkurencyjnej, PWE, Warszawa 1998, s. 235.

${ }^{51}$ Zaktualizowana koncepcja przestrzennego zagospodarowania kraju, Rządowe Centrum Studiów Strategicznych, Warszawa, październik 2005, za: www.funduszestrukturalne.gov.pl/informator/npr2/dokumenty strategiczne/kpzk.pdf [z dn. 25.10.2011].
} 
cesem akcesyjnym przyjęcia Polski do Unii Europejskiej oraz pierwszym okresem tuż po akcesjij ${ }^{52}$.

2. Perspektywa średniookresowa - obejmująca okres do roku 2015, czyli czas integracji z Unią Europejska, dostosowania wymogów cywilizacyjnych, gospodarczych, społecznych i środowiskowych do obecnie obowiązujących w Unii. Szansa na rozwój poprzez wykorzystanie funduszy unijnych, strukturalnych, oferujacych bogaty wachlarz możliwości we wszystkich dziedzinach gospodarki województwa, ze szczególnym naciskiem na infrastrukturę techniczną. Istnieje możliwość głębokiej restrukturyzacji i modernizacji poszczególnych obszarów funkcjonalnych regionu. To prawdziwy sprawdzian dla władzy wszystkich szczebli samorządowych, która poprzez wykorzystanie naturalnych walorów i odpowiedniego położenia regionu łódzkiego może maksymalnie wykorzystać nadarzające się okazje w ujęciu przestrzennym dla miejskich aglomeracji, a także terenów wiejskich.

3. Perspektywa długookresowa - obejmujaca okres po 2015 r., o tyle ważna, o ile sprawnie i skutecznie wykorzystany będzie czas dla planowania średniookresowego. Dobrze zaplanowane procesy rozwojowe z lat wcześniejszych skutkować będą samorzutną kontynuacja zapoczątkowanych działań ${ }^{3}$.

Mówiąc o przyszłej koncepcji i pomyśle na nowe oblicze regionu łódzkiego, trzeba omówić jego obecną sytuację pod względem funkcjonalnym i przestrzennym, ze szczególnym uwzględnieniem infrastruktury drogowej i lotniczej.

Pod względem stopnia zurbanizowania województwo łódzkie zajmuje obecnie piąte miejsce w skali kraju54. Dość gęsta sieć dróg o znaczeniu krajowym ${ }^{55}$ i międzynarodowym ze względu na dogodne położenie

${ }^{52} \mathrm{Na}$ mocy tzw. Traktatu akcesyjnego podpisanego w Atenach 16 kwietnia 2003 r., a stanowiącego podstawę prawna przystąpienia Polski do Unii Europejskiej, nasz kraj stał się członkiem UE od 1 maja 2004 r. Zmiany ustrojowe zapoczątkowane w 1998 r. umożliwiły rozpoczęcie procesu integracji z krajami Wspólnoty Europejskiej. W Parlamencie Europejskim zasiada 51 polskich eurodeputowanych, a Polska jako pełnoprawny członek UE sprawuje prezydencję do końca 2011 r., za: M. Kałużyńska, Polska prezydencja w Unii Europejskiej - jak pomyślnie zdać europejski egzamin dojrzałości?, "Biuletyn Analiz UKIE”, listopad 2009, nr 22, s. 5.

53 Opracowanie własne na podstawie Syntezy „Planu zagospodarowania przestrzennego województwa łódzkiego", s. 5.

${ }^{54}$ Regionalny Program Operacyjny Województwa Łódzkiego na lata 2007-2013, rozdział 1.

55 Ustawa z dn. 21 marca 1985 r. o drogach publicznych, Dz.U. z 1985 r., nr 14, poz. 60 z późn. zm., rozdział 1, art. 2.1 . 
regionu cechuje się nasilonym ruchem tranzytowym. Widoczne jest to w szczególności na drogach krajowych, które przebiegaja przez region łódzki:

- nr 1 Gdańsk-Toruń-Łódź-Piotrków Trybunalski-Katowice-Cieszyn,

- nr 2 Warszawa-Kutno-Krośniewice-Poznań,

- nr 8 Warszawa-Piotrków Trybunalski-Bełchatów-Wieluń-Wrocław,

- nr 12 Piotrków Trybunalski-Radom-Lublin-granica państwa,

- nr 14 Łowicz-Łódź-Łask-Walichnowy,

- nr 72 Konin-Łódź-Rawa Mazowiecka ${ }^{56}$.

Największe dobowe nasilenie ruchu drogowego odczuwalne jest na drogach krajowych nr 1, nr 2 i nr 8, gdyż stanowią one "najważniejszy element układu drogowego województwa [...] przenoszący główny ciężar ruchu międzynarodowego w relacjach północ-południe i wschódzachód"57. Centrum województwa i sama aglomeracja łódzka także generuje duży ruch drogowy, porównywalny tylko z aglomeracjami krakowską i poznańską58. Na sieć komunikacyjną województwa łódzkiego oprócz dróg krajowych (autostrady i drogi ekspresowe) składaja się również drogi będące pod zarządem wojewódzkim, powiatowym i gminnym.

Mimo dogodnego położenia, istotnym problemem województwa jest obecnie niedostateczny stan techniczny infrastruktury drogowej, lotniczej i kolejowej. Sytuacja ulegnie znaczącej zmianie z chwila powstania Centralnego Węzła Komunikacyjnego wokół Łodzi. W ramach tej inwestycji planuje się budowę autostrad A1 i A2, dróg ekspresowych S8 i S14, drogi ekspresowej S74 Łódź-Kielce, szybkiej kolei łączącej Łódź z Wrocławiem i Warszawą oraz rozwój regionalnych portów lotniczych Łódź Lublinek i lotnisko cargo w Łasku ${ }^{59}$.

Dobrze rozwinięty system transportu kołowego i lotniczego może dać duży impuls dla rozwoju gospodarczego danego regionu. Takim impulsem w przypadku regionu środkowej Polski byłoby na pewno stworzenie lotniska cargo $w$ Łasku, gdzie na zasadzie współistnienia mógłby funkcjonować duży port cywilny obsługujący przepływ towarów i produktów. Obecnie istnieje tam 32 Baza Lotnictwa Taktycznego. Centralne położenie oraz możliwość poprawy istniejacej infrastruktury transportowej stwarza warunki, jakich nie ma $w$ wielu innych regionach

\footnotetext{
${ }^{56}$ www.siskom.waw.pl/DK [z dn. 28.10.2011].

57 Plan działania systemu Państwowe Ratownictwo Medyczne dla województwa łódzkiego, Łódź, styczeń 2011.

${ }^{58}$ Założenia aktualizacji strategii rozwoju województwa łódzkiego do roku 2020, s. 12.

${ }^{59}$ Opracowanie własne na podstawie www.gddkia.gov.pl [z dn. 20.10.2011].
} 


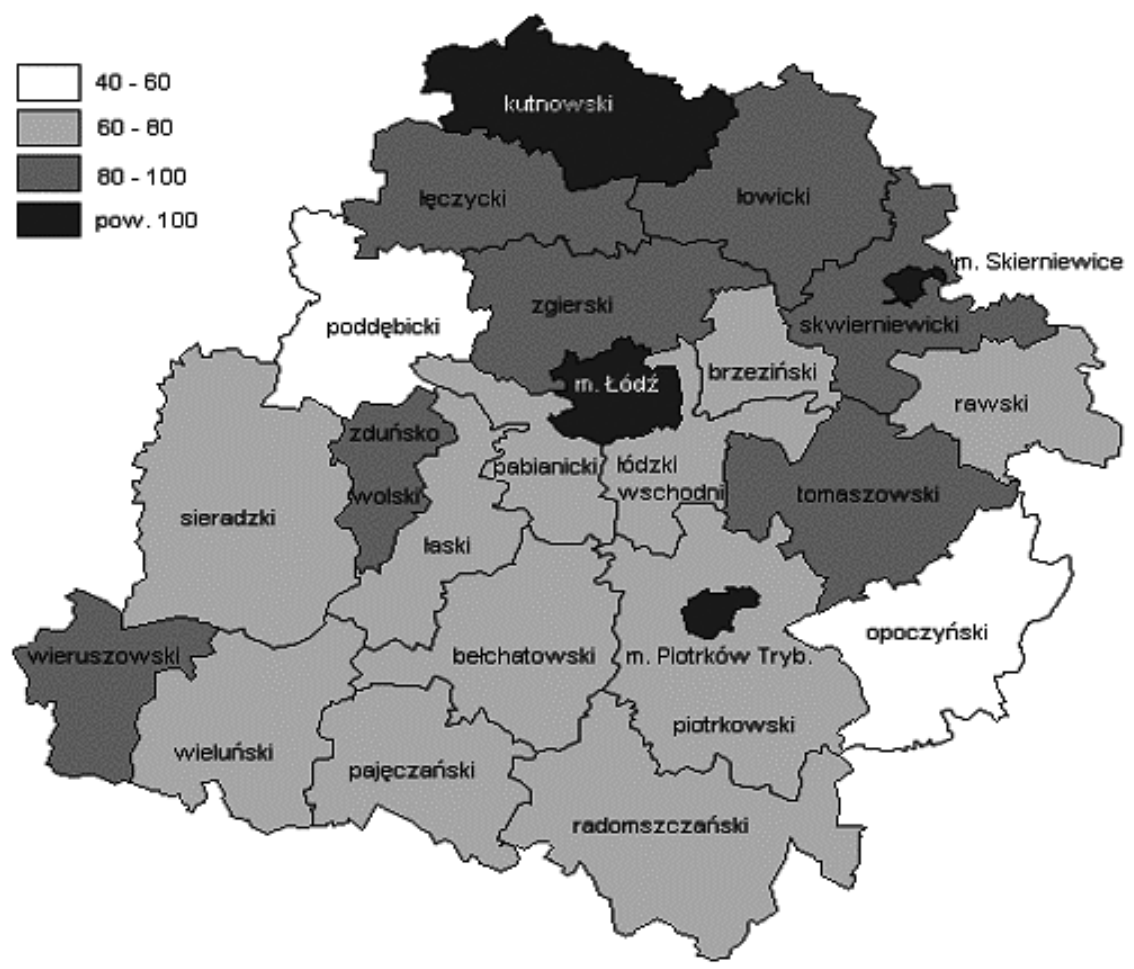

Mapa 5. Gęstość dróg powiatowych i gminnych o twardej nawierzchni w woj. łódzkim - stan na 2004 r.

Źródło: Regionalny Program Operacyjny Województwa Łódzkiego na lata 2007-2013, wyd. Urząd Marszałkowski, Łódź, wrzesień 2007, s. 7

naszego kraju. Dodatkowym bodźcem do zbudowania lotniska cargo jest niższy koszt utrzymania powierzchni magazynowych w porównaniu z innymi lokalizacjami, a także bliskość dużych rynków konsumenckich, co niewattpliwie stanowi kolejny argument do działania na rzecz rozwoju gałęzi gospodarki, jaką jest logistyka i spedycja. Z pewnością działania zmierzające $\mathrm{w}$ tym celu powinny skupić się na włączeniu przedmiotowego lotniska do Transeuropejskiej Sieci Transportowej - TEN-T60. Byłoby to korzystne dla finansowania przygotowywanych projektów, spowodowałoby poprawę mobilności mieszkańców i poczucie realnej więzi z krajami europejskimi.

60 TEN-T - Transeuropejska Sieć Transportowa, obejmująca swym zasięgiem m.in. infrastrukturę transportowa. Jest to koncepcja stworzenia jednolitej sieci powiazań transportowych, podnosząca mobilność towarów na terenie całej wspólnoty europejskiej, za: www.ulc.gov.pl [z dn. 29.10.2011]. 


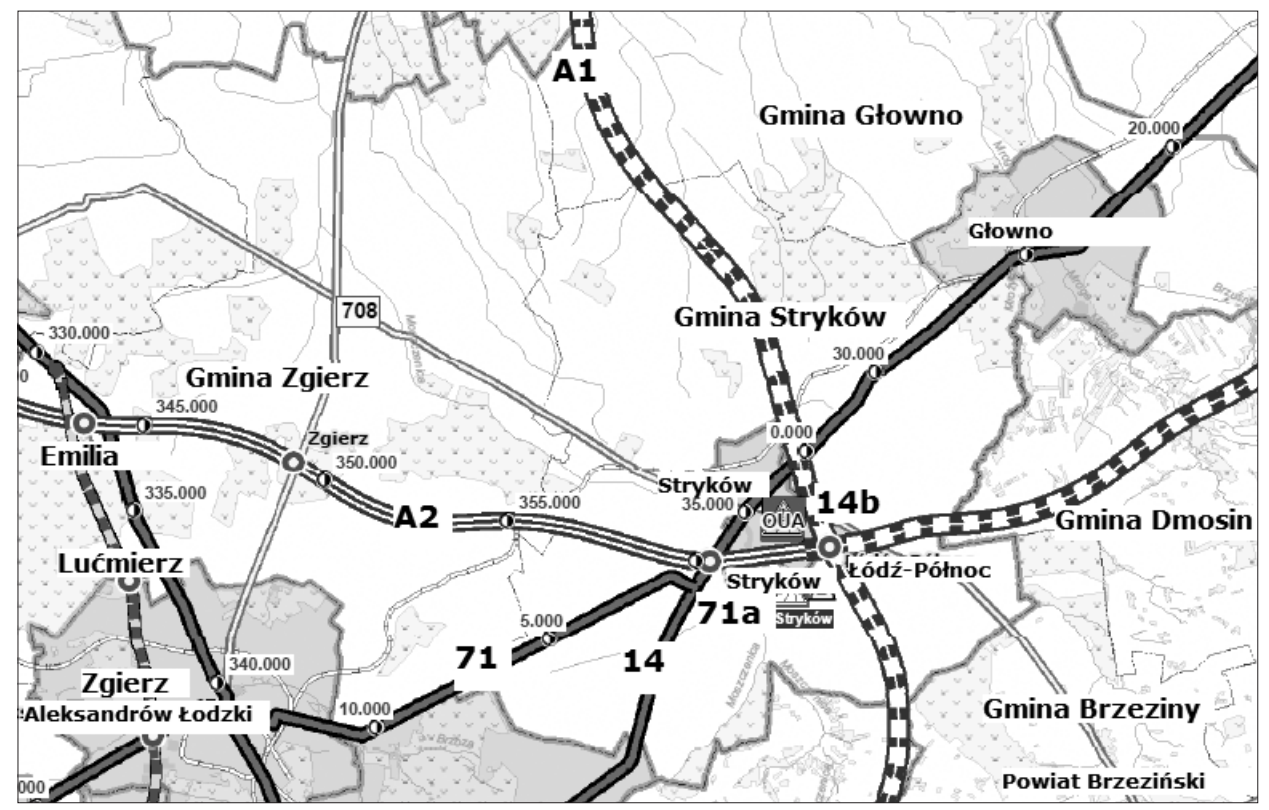

Mapa 6. Fragment Centralnego Węzła Komunikacyjnego wokół Łodzi Źródło: opracowanie - Anna Zmysłowska

\subsection{Lotnisko towarowo-cywilne szansą rozwoju regionu}

Niebagatelny wpływ na wszystkie dziedziny życia ma odpowiednia lokalizacja danego miasta względem głównych szlaków transportowych. Z punktu widzenia szeroko pojętego rozwoju regionalnego w dzisiejszych czasach jest bardzo istotne, aby nadą̇yć za tempem życia, nie pozostając $w$ tyle, a poziom rozwoju każdej dziedziny dostosować do ciaggle zmieniających się standardów i niestabilnego otoczenia, stawiającego przed uczestnikami życia społeczno-ekonomicznego coraz to wyższe wymagania. Rozwój transportu krajowego i międzynarodowego można realizować nie tylko w oparciu o tabor samochodowy. Niebagatelnego znaczenia w momencie, gdy świat stał się globalną wioską, nabiera również możliwość korzystania z transportu lotniczego, jako środka bardziej bezpiecznego i majaccego większy zasięg. Region Polski Centralnej stanowi najlepsza z możliwych lokalizację dla przedsięwzięć i inwestycji, w których priorytetową rolę odgrywa transport lotniczy. Warto więc wykorzystać nadarzająca się okazję.

Przedmiotem niniejszego podrozdziału jest przedstawienie możliwego do osiagnięcia, konkretnego celu w postaci budowy lotniska cargo w Łasku. Rozwój regionu gospodarczego wokół miasta Łask ma duże 
szanse w perspektywie realizacji śmiałych planów inwestycyjnych. Moga one w przyszłości mieć pozytywne skutki we wszystkich niemal dziedzinach gospodarki regionu. Warto pochylić się nad tym zagadnieniem, szczególnie w momencie, kiedy Polska ma duże możliwości korzystania $z$ funduszy strukturalnych oraz dotacji celowych na inwestycje ${ }^{61}$ ściśle związane z rozwojem infrastruktury transportowej62. Ekspertyza wykonana na zamówienie Ministerstwa Rozwoju Regionalnego zakłada "rozwój transportu lotniczego poprzez budowę i unowocześnienie lotnisk o zasięgu międzynarodowym oraz regionalnych, a także poprawę infrastruktury dojazdowej"63.

Jak wiadomo, różne dziedziny gospodarki narodowej funkcjonują jak naczynia połączone, a jedne działania determinuja kolejne, skutkując późniejszymi zmianami. To ma miejsce również $w$ przypadku ładu funkcjonalno-przestrzennego, w którym transformacja zachodzi zdecydowanie wolniej, pochłania relatywnie większe środki finansowe, generujac koszty dla gospodarki narodowej, ale korzyści skali są nieporównywalne, przekraczające niekiedy ramy opracowywanych analiz i ekspertyz dotyczących bezpośrednio danego działania sektorowego ${ }^{64}$. Ważnym zagadnieniem jest również aspekt zabezpieczenia obronnego i jego uwarunkowań w ujęciu zagospodarowania przestrzennego kraju tam, gdzie istnieje potrzeba korelacji na styku władz terytorialnych i wojska. Konieczny punkt odniesienia dla tego problemu zawiera się w kilku aktach prawnych, określających szczególne potrzeby sił zbrojnych oraz wymogi co do obronności nie tylko granic naszego państwa, lecz także zewnętrznej granicy Unii Europejskiej. Ustawa o planowaniu i zagospodarowaniu przestrzennym określa warunki istnienia terenów zamkniętych ${ }^{65}$, czyli terenów "0 charakterze zastrzeżonym ze względu

${ }^{61}$ Inwestycja celu publicznego - są to wszelkiego rodzaju działania o charakterze gminnym, wojewódzkim, krajowym lub międzynarodowym, w których dochodzi do zrealizowania zamierzeń publicznych, w szczególności dotyczących budowy i utrzymania obiektów służących ochronie środowiska, urządzeń użyteczności publicznej, takich jak drogi, wodociągi, kanalizacja oraz stanowiących dobra kultury, służących potrzebom obronności państwa itp., za: ustawa z dnia 21 sierpnia 1997 r. o gospodarce nieruchomościami, Dz.U. z 1997 r., nr 115, poz. 741, dział I, art. 6.

62 M. Wolański, Rozwój infrastruktury transportowej w latach 2007-2010 w kontekście dotychczasowej Strategii Rozwoju Kraju 2007-2015 oraz kluczowych strategii sektorowych, opracowanie sporządzone na zlecenie Ministerstwa Rozwoju Regionalnego, Warszawa 2011.

63 Tamże, s. 5.

64 Zaktualizowana koncepcja przestrzennego zagospodarowania kraju, s. 87.

65 Ustawa z dn. 27 marca 2003 r. o planowaniu i zagospodarowaniu przestrzennym, Dz.U. z 2003 r., nr 80, poz. 717 z późn. zm., rozdział 1, art. 4. 
na obronność i bezpieczeństwo państwa"66. Analizując możliwość zlokalizowania omawianego lotniska cargo w okolicach miasta Łask, trzeba koniecznie poruszyć zagadnienia wojskowe, gdyż przedmiotowe lotnisko cargo miałoby powstać przy istniejącym już lotnisku wojskowym, na którym stacjonuje i funkcjonuje w trybie lotów bojowych 32 Baza Lotnictwa Taktycznego. Taka lokalizacja jest jak najbardziej zasadna z uwagi na obszar, który miałoby to lotnisko obsługiwać.

W zasięgu strefy funkcjonowania przyszłego lotniska cargo zlokalizowane jest miasto Łask, jedno z kilkudziesięciu leżących w obrębie województwa łódzkiego. Stanowi ono swoistego rodzaju zaplecze dla aglomeracji łódzkiej. Mieszkańcy miasta i gminy Łask chętnie szukaja tam pracy i ja znajduja, korzystaja z szerokiej oferty edukacyjnej, maja sposobność uczestniczenia w życiu kulturalnym stolicy regionu. Coraz częściej mieszkańcy Łasku traktują atrakcje wielkomiejskiej aglomeracji jako odskocznię od życia codziennego, spędzając weekendy w kompleksach handlowo-rozrywkowych.

Gmina Łask, licząca $145,37 \mathrm{~km}^{2}$ powierzchni67, po reformie administracyjnej w 1999 r. ponownie znalazła się w obrębie województwa łódzkiego ${ }^{68}$. Obszar ten zamieszkany jest przez prawie 30 tys. ludzi69, skupionych głównie w ośrodku miejskim. Miasto stanowi nie tylko administracyjna stolicę regionu, lecz także siedzibę władz powiatowych. Sasiednie powiaty przedstawiono $w$ tab. 2 .

Stolice wymienionych powiatów to duże miasta województwa łódzkiego, rozwijające się w dużym stopniu dzięki skutecznemu działaniu zdeterminowanych ludzi na rzecz rozwoju regionalnego i lokalnego. W ramach dążenia do zrównoważonego rozwoju ${ }^{70}$ regionu powołano "Stowarzyszenie Gmin i Powiatów na rzecz budowy dróg ekspresowych S-8 i S-14". Jego współtwórca i inicjatorem jest senator Ziemi Łódzkiej, mieszkaniec Łasku, Andrzej Owczarek ${ }^{71}$.

${ }^{66}$ Ustawa z dn. 17 maja 1989 r. Prawo geodezyjne i kartograficzne, t.j. Dz.U. z 2005 r., nr 240, poz. 2027, rozdział 1, art. 2.

${ }^{67}$ I. Budzyński (red.), Powierzchnia i ludność w przekroju terytorialnym w 2011 r., GUS, Warszawa 2011, s. 86.

${ }^{68}$ Ustawa z dn. 24 lipca 1998 r. o wprowadzeniu zasadniczego trójstopniowego podziału terytorialnego państwa, Załącznik.

${ }^{69}$ I. Budzyński (red.), Powierzchnia i ludność..., s. 86.

70 Zrównoważony rozwój - oznacza rozwój społeczno-gospodarczy integrujący działania polityczne, społeczne i gospodarcze, które dążą do zachowania równowagi przyrodniczej w celu zagwarantowania współczesnym i przyszłym pokoleniom zaspokojenie ich podstawowych potrzeb, za: ustawa z dn. 27 kwietnia 2001 r. Prawo ochrony środowiska, Dz.U. z 2001 r., nr 62, poz. 627 z późn. zm., dział II, art. 3, pkt. 50.

717 kwietnia 2008 r. odbyło się spotkanie założycielskie przedstawicieli władz gminnych i powiatowych regionu łódzkiego, na którym sporządzono protokół powołujący do 
Tabela 2. Wykaz powiatów przyległych do powiatu łaskiego

\begin{tabular}{|c|l|c|}
\hline Lp. & \multicolumn{1}{|c|}{ Nazwa powiatu } & Powierzchnia w $\mathrm{km}^{2}$ \\
\hline 1. & Bełchatowski & 968 \\
\hline 2. & Pabianicki & 492 \\
\hline 3. & Poddębicki & 881 \\
\hline 4. & Sieradzki & 1491 \\
\hline 5. & Wieluński & 926 \\
\hline 6. & Zduńskowolski & 369 \\
\hline
\end{tabular}

Źródło: I. Budzyński (red.), Powierzchnia i ludność w przekroju terytorialnym w 2011 r., GUS, Warszawa 2011, s. 20.

Powiat łaski, jak wiele jemu podobnych, miał różne koleje dziejowe. Pierwsze wzmianki o nim datowane sa na rok $1867^{72}$. Walki i okupacja hitlerowska, a następnie przemiany administracyjne za czasów poprzedniego układu politycznego, takie jak wprowadzenie nowych jednostek samorządowych w postaci gromad czy też nadawanie tytułu osad tymczasowym osiedlom, nadwątliły znaczenie i prestiż powiatu łaskiego, który ostatecznie w 1975 r. utracił prawa odrębności samorzadowej, zaś Łask ${ }^{73}$ stał się siedzibą Urzędu Rejonowego. Nowa reforma administracyjna w 1999 r. sprawiła, że Łask stał się ponownie siedzibą powiatu. Niestety, reforma ta, nie uwzględniając powiązań osadniczo-przestrzennych ani związków historycznych, wyłączyła związana dotąd z Łaskiem gminę Dobroń74, co skutkowało okrojeniem obszaru powiatu do $618,23 \mathrm{~km}^{2}$. Obecnie z powiatem łaskim powiązane są administracyjnie cztery gminy. Należą do nich: gmina Buczek, Sędziejowice, Widawa oraz Wodzierady.

Miasto Łask jest dziś nie tylko ośrodkiem administracyjnym, lecz także rozwijającym się centrum usługowym, kulturalno-oświatowym i turystycznym. Obecnie na terenie gminy Łask działa około 2 tys. podmio-

życia "Stowarzyszenie Jednostek Samorządu Terytorialnego na rzecz budowy dróg ekspresowych S-8 (przez Sieradz-Łódź) i S-14". Gospodarzem spotkania był starosta Łasku Cezary Gabryjączyk, za: materiały udostępnione przez Biuro Senatorskie Senatora RP Andrzeja Owczarka.

${ }^{72}$ Opracowanie własne na podstawie: www.lask.com.pl/Powiat-Łaski/Historia.aspx [z dn. 26.11.2012].

73 Miasto Łask otrzymało prawa miejskie w 1422 r., za: Encyklopedia Powszechna, t. 2, s. 796 .

${ }^{74}$ I. Budzyński (red.), Powierzchnia i ludność..., s. 20. 
tów gospodarczych. W mieście rozwija się rzemiosło, usługi i przemysł. Tereny miejskie posiadaja dobrze rozwiniętą infrastrukturę techniczna. Należy tu wspomnieć o nowoczesnej, spełniającej normy europejskie oczyszczalni ścieków, w której dzięki nowoczesnym technologiom pozyskane z efektywnego suszenia odpady przeznacza się ponownie do energetycznego zagospodarowania w spalarniach, czy też do dalszego rolniczego wykorzystania ${ }^{75}$. Dzięki zakrojonym na szeroką skalę działaniom władz miejskich gmina pozyskała dotacje z Unii Europejskiej na wybudowanie sieci kanalizacyjnej w samym mieście, a także w pobliskich wsiach. W 2012 r. realizuje się na terenie gminy zadania inwestycyjne, w ramach których kolejni mieszkańcy przyłączani są do nowej sieci kanalizacyjnej.

Ze względu na swoje położenie miasto Łask jest ważnym węzłem komunikacyjnym. Obszar gminy przecina kilka tras ruchu kolejowego ${ }^{76}$ oraz ważne z punktu widzenia przewozu osobowego drogi krajowe i wojewódzkie.

Dzięki krzyżowaniu się tak wielu dróg różnego zaszeregowania, miasto Łask wpisuje się w komunikacyjny szlak europejski. Dodatkowo, z punktu widzenia przestrzeni transportowej w niewielkiej odległości, bo około $35 \mathrm{~km}$ od Łasku, przebiegaja skrzyżowania ważnych autostrad: A2 (Berlin-Moskwa) oraz A1 (Kaliningrad-Gdańsk-południe Europy), wpisując się w transeuropejski korytarz komunikacyjny północ-południe i wschód-zachód.

Tabela 3. Zestawienie dróg przebiegających przez miasto Łask

\begin{tabular}{|c|l|l|}
\hline Nr drogi & \multicolumn{1}{|c|}{$\begin{array}{c}\text { Przynależność } \\
\text { terytorialna }\end{array}$} & \multicolumn{1}{c|}{ Punkty docelowe trasy } \\
\hline 12 & krajowa & Łask, Piotrków Trybunalski, Radom, Lublin \\
\hline 14 & krajowa & Łowicz, Łódź, Łask, Walichnowy \\
\hline 473 & wojewódzka & Łask, Koło \\
\hline 483 & wojewódzka & Łask, Częstochowa \\
\hline 481 & wojewódzka & Łask, Wieluń \\
\hline
\end{tabular}

Źródło: opracowanie - Anna Zmysłowska.

75 B. Lisiecki (red.), „Panorama Łaska” 2009, nr 5/87 (maj).

76 Magistrala węglowa Śląsk-Porty - zbudowana w latach 1926-1933, stanowiła doskonałe połączenie Górnego Śląska z Gdańskiem, była niespotykana jak na ówczesny okres inwestycją komunikacyjna, wyróżniała się dużym nasileniem przepływu towarów, w szczególności węgla kamiennego, za: Encyklopedia Powszechna, t. 2, s. 827. 
Uwzględniając zatem wszystkie wspomniane aspekty wynikające z dogodnego położenia Łasku, przebiegajace oraz krzyżujące się drogi, a także bliskość magistrali kolejowej Ślask-Porty w Karsznicach, majacej dużej znaczenie dla przewozów towarowych, w wielu dokumentach regulujących ład przestrzenny ${ }^{77}$ zawarto perspektywę budowy lotniska cargo. Przewidziano też możliwość działania firm oferujących profesjonalną obsługę logistyczna, spedycję towarów na dużą skalę, a także budowę wielkich centrów magazynowych pracujacych całodobowo. Inwestycja w postaci lotniska towarowego ma przynieść wymierne korzyści finansowe. Ma być finansowana głównie ze środków pochodzących od przedsiębiorców, ale również z funduszy unijnych. Firmy zlokalizowane w województwie łódzkim czekaja na rozpoczęcie tak ważnej inwestycji. Rozmiar projektu opracowanego przez Spółkę "Lotnisko Łask" zobrazowano na mapie 7.

Klamra spinająca to ogromne przedsięwzięcie jest budowa drogi ekspresowej S8, dzięki której zdecydowanie skróci się czas transportu, obniżą się koszty eksploatacji i być może nastapi spadek cen usług spedycyjnych i kurierskich. Przedsięwzięcie tej rangi może przyciągnąc również inwestorów z innych branż. Zaczną się rozwijać usługi gastronomiczne i hotelarskie. Nastapi rozwój sieci sklepów wielkopowierzchniowych, oferujących sprzedaż dóbr wszelkiego asortymentu. Potrzeba coraz większej liczby wykwalifikowanej kadry i pracowników będzie skutkować migracją ludzi z innych regionów kraju, którzy przyjadą tutaj w poszukiwaniu dobrze płatnej pracy. Ta samonapędzająca się machina zataczać będzie coraz szersze kręgi z korzyścią dla naszego miasta, województwa i regionu. Przedstawione perspektywy ożywienia gospodarczego i szanse rozwoju są związane z istnieniem wojskowej bazy lotniczej w mieście Łask.

Sam pomysł powstania i uruchomienia lotniska towarowego właśnie w pobliżu bazy lotniczej nie jest pomysłem nowym. Już od kilkunastu lat trwaja prace wspomagające tę inicjatywę. Pomocna w realizacji tego projektu jest "Lotnisko Łask" Sp. z 0.0.78, której głównym zadaniem jest dotarcie do jak największej liczby potencjalnych inwestorów, szukanie sponsorów i ogólne lobbowanie na rzecz tego przedsięwzięcia.

77 Założenia aktualizacji strategii rozwoju województwa łódzkiego do roku 2020, rozdział II, pkt 1.4, ppkt 8, s. 13; uchwała nr XVIII/137/08 Rady Miejskiej w Łasku z dn. 6 lutego 2008 r. w sprawie uchwalenia zmiany "Studium uwarunkowań i kierunków zagospodarowania przestrzennego miasta i gminy Łask", s. 64.

${ }^{78}$ www.lodz-sitk.org.pl/news/pliki/IV-kompleks\%20logistyczny\%20Lask.pdf [z dn. 16.10.2009]. 


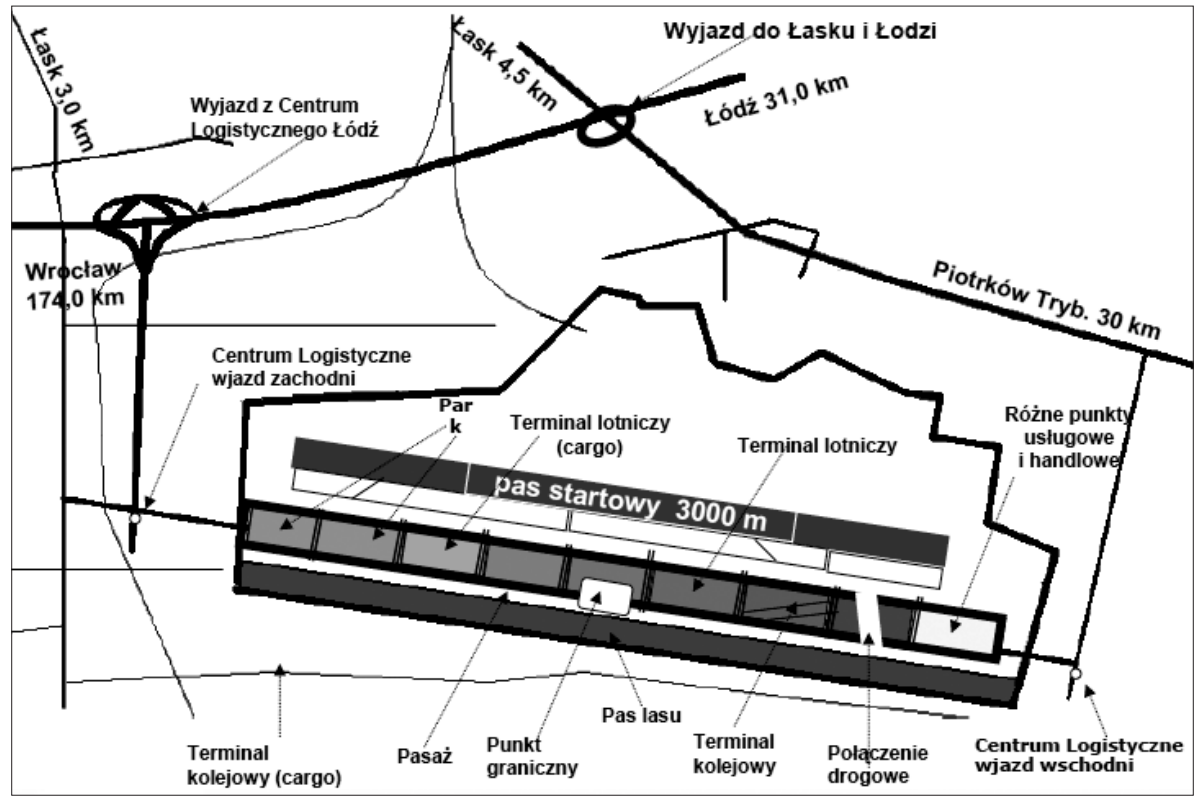

Mapa 7. Projekt kompleksu logistycznego zaproponowanego przez Spółkę "Lotnisko Łask"

Źródło: materiały „Lotnisko Łask” Sp. z o.o., Łódź 2006

32 Baza Lotnictwa Taktycznego ${ }^{79}$ również nie uchyla się od współpracy. Jest ściśle powiązana z regionem, w którym stacjonuje. Przychylne dowództwo i kadra wojskowa utrzymuje kontakty z władzami powiatu i gmin, na których terytorium leży lotnisko. Zacieśnianie współpracy i budowanie dobrych relacji z lokalnymi władzami oraz instytucjami administracyjnymi, społecznymi i kulturalnymi to podstawa współdziałania w każdej organizacji. Zrozumienie dla podejmowanych kroków wykazano również na najwyższym szczeblu władzy państwowej. 11 grudnia 2007 r. premier Donald Tusk złożył na ręce Marszałka Sejmu projekt ustawy zmieniającej ustawę o gospodarowaniu niektórymi składnikami Skarbu Państwa oraz o Agencji Mienia Wojskowego, która po dość długiej ścieżce legislacyjnej dnia 10 lipca 2008 r. została przyjęta przez Sejm RP ${ }^{80}$. Premier jako swojego reprezentanta przedstawił

7932 Baza Lotnictwa Taktycznego (32BLT) powstała 1 stycznia 2010 r. po przeformowaniu z dotychczasowej 32 Bazy Lotniczej oraz 10 Eskadry Lotnictwa Taktycznego, za: www.32blot.wp.mil.pl/pl/67.html.

80 Ustawa z dn. 10 lipca 2008 r. o zmianie ustawy o gospodarowaniu niektórymi składnikami mienia Skarbu Państwa oraz Agencji Mienia Wojskowego oraz o zmianie niektórych innych ustaw, Dz.U. z 2008 r., nr 144, poz. 901. 


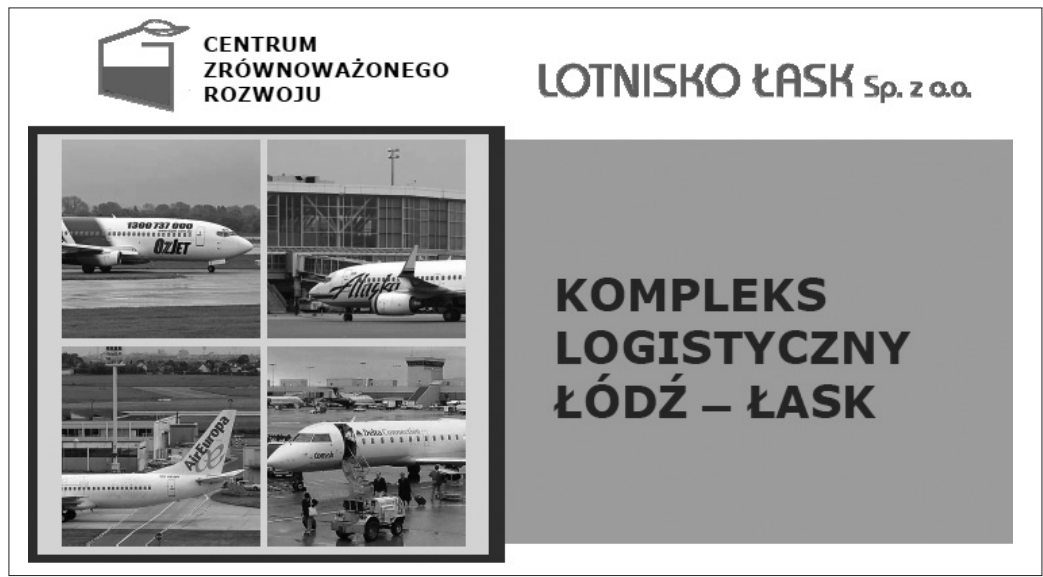

Rysunek 1. Logo Spółki "Lotnisko Łask"

Źródło: materiały „Lotnisko Łask” Sp. z o.o., Łódź 2006

ministra infrastruktury. W uzasadnieniu projektu ustawy, we fragmencie dotyczącym wykorzystania lotnisk wojskowych możemy przeczytać, że: „Projektowana zmiana ustawy [...] ma na celu wprowadzenie regulacji prawnych, które umożliwia zwiększenie efektywności wykorzystania lotnisk wojskowych, będących w dyspozycji jednostek resortu obrony narodowej [...]. Przyczyni się to do optymalizacji realizacji polityki transportowej w zakresie lotnictwa cywilnego przez rozwój cywilnej infrastruktury lotniskowej, niezbędnej do zaspokojenia potrzeb szybko rosnącego ruchu lotniczego, na bazie istniejącej krajowej infrastruktury lotniskowej, co w efekcie obniży koszty tworzenia sieci lotnisk cywilnych na terenie kraju"81. Jak wnioskujemy z przytoczonego uzasadnienia, resorty obrony i infrastruktury moga ze soba ściśle współpracować, a ma to ułatwić szeroko zakrojona praca legislacyjna nad ustawą i chęć obu stron do zrozumienia istotnej problematyki transportu powietrznego i drogowego.

Prace nad projektem lotniska towarowego trwały w kilku departamentach resortu. Według prezesa Spółki "Lotnisko Łask", będącej spółką Skarbu Państwa i samorządów, chęć współpracy zadeklarowali także znani inwestorzy z województwa łódzkiego: DELL, Indesit oraz Gillette ${ }^{82}$, które przewiduja wydatne korzyści finansowe dla swoich przedsię-

${ }^{81}$ Uzasadnienie wniosku do projektu ustawy, za: www.premier.gov.pl [z dn. 22.08.2011].

82 Opracowanie własne na podstawie materiałów uzyskanych w siedzibie "Lotnisko Łask" Sp. z o.o. 12 listopada 2011 r. 
biorstw z tytułu obniżenia kosztów transportu i dostępności powierzchni magazynowych. Zarówno władze powiatowe, jak i gminne od dawna są przekonane o słuszności powstania takiej inwestycji w okolicy Łasku.

Jednak koncepcja funkcjonowania cywilnego lotniska cargo w symbiozie z wojskowym portem lotniczym nie jest do końca właściwa z punktu widzenia zarządcy terenu - w tym przypadku chodzi głównie o odpowiednie podejście do tego zagadnienia przedstawicieli Ministerstwa Obrony Narodowej83. W decyzji nr 236 pierwotnie wojskowe lotnisko w Łasku znalazło się w wykazie lotnisk, które moga być udostępnione stronie cywilnej celem wykorzystania na potrzeby lotnictwa cywilnego. Jednak droga legislacyjna, wymagająca przede wszystkim dobrej woli przedstawicieli władz, okazała się "droga cierniową". Rozporządzenie Rady Ministrów ${ }^{84} \mathrm{w}$ kolejnych latach wykreśliło przedmiotowe lotnisko w Łasku ze wspomnianego wykazu, niejako zamykając drogę dla kolejnych poczynań. Dodatkowo lotnisko to nie jest ujęte w sieci TEN-T, co jak się wydaje - jest niezbędnym i kluczowym wymogiem do finansowania takiego przedsięwzięcia ze środków i dotacji unijnych ${ }^{85}$.

Obecnie potrzeba dużej determinacji i zapału ludzi, którzy moga decydować o przyspieszeniu tego rodzaju inwestycji. Wewnętrzne spory o przynależność terytorialna, animozje i spóźnione żale na pewno nie przysłuża się i nie przybliża realizacji lotniska cargo. Władze gminy i powiatu Łask powinny zjednoczyć siły i dążyć do wspólnego rozwiązwania narastających problemów; wypracować stanowisko, które będzie gwarantowało intensyfikację działań dla wspólnego dobra. Dla naszego regionu jest to jedyna słuszna droga, jaką powinniśmy obrać.

\subsection{Przewidywane rozmiary i koszty inwestycji}

Jak powiedział Owidiusz, „kropla drąży skałę", dlatego też nigdy nie należy wycofywać się z raz obranego kierunku, nawet wtedy, gdy oznacza to krążenie po omacku lub podążanie wyboistymi, krętymi

${ }^{83}$ Decyzja MON nr 236 z dn. 28 grudnia 1998 r. przedstawiająca wykaz lotnisk wojskowych, które moga być wykorzystywane na potrzeby lotnictwa cywilnego, za: www.arturdunin.h2.pl/wordpress/?p=16 [z dn. 31.10.2011].

${ }^{84}$ Rozporządzenie Rady Ministrów z dnia 24 grudnia 2008 r. w sprawie wykazu lotnisk wojskowych, które moga być wykorzystane na potrzeby lotnictwa cywilnego, Dz.U. z 2009 r., nr 3, poz. 12 - wykluczono możliwość istnienia lotniska cywilnego w Łasku, za: www.arturdunin.h2.pl/wordpress/?p=16 [z dn. 31.10.2011].

${ }^{85}$ Opracowanie własne na podstawie materiałów udostępnionych przez Biuro Senatorskie Senatora RP Andrzeja Owczarka, za: Memorandum, oprac. Kancelaria Prawna BAKER \& MCKENZIE Gruszczyński i Wspólnicy, Warszawa, 23 października 2006 r. 
ścieżkami, aż do osiągnięcia wyznaczonego celu. Wiele można przytoczyć przykładów na potwierdzenie powyższych słów. Najlepszym z nich jest wielka determinacja i zaangażowanie ludzi, przedstawicieli samorządów terytorialnych oraz zainteresowanych środowisk lokalnych na rzecz zmiany przebiegu drogi ekspresowej S8, która po niefortunnej decyzji urzędniczej miała przebiegać zupełnie innym korytarzem niż obecnie $^{86}$. Opierając się na tym przykładzie, można wysnuć wnioski, że nie należy się poddawać, nawet w przypadku, gdy okoliczności dotyczą z pozoru beznadziejnej sprawy, a stan rzeczy określić można tylko słowem "pat".

Podobnie wygląda obecnie sytuacja koncepcji budowy kompleksu logistycznego, w ramach którego miałoby powstać towarowe cywilne lotnisko w Łasku. Jak wynika z Założeń do koncepcji funkcjonalno-przestrzennej lotniska Łask ${ }^{87}$, plany zakładaja współistnienie terminalu cywilnego na równi z wojskowym kompleksem lotniskowym. Trzeba tutaj dodać, że lotnisko wojskowe $\mathrm{w}$ Łasku istnieje od lat 50. ubiegłego wieku. Od 1957 r. na terenie lotniska i jednostki wojskowej istniał 10. Pułk Lotnictwa Myśliwskiego, który przez prawie 40 lat stacjonował na gościnnej ziemi łaskiej. Jednostka wojskowa i kompleks lotniczy jest największym atutem miasta Łask, stwarzającym potencjalnie najszersze pole do rozwoju, nie tylko komunikacji i transportu, ale całej infrastruktury technicznej dla regionu. Baza lotnicza jest ponadto największym pracodawca w regionie. Według danych na 2012 r., zatrudnia ponad 1,3 tys. żołnierzy zawodowych i pracowników cywilnych. Pracę $w$ bazie znaleźli specjaliści z różnych branż, pracownicy cywilni i kadra zawodowa.

Lotnisko wojskowe w Łasku jest dobrym przykładem na zilustrowanie działania Programu Inwestycji w dziedzinie bezpieczeństwa NSIP88. Część zadań infrastrukturalnych, które obecnie sa prowadzone na terenie kompleksu lotniskowego, finansowana jest ze środków i dotacji celowych oraz podmiotowych NATO. Inwestorem i dysponentem tych środków jest Zakład Inwestycji Organizacji Traktatu Północnoatlanty-

${ }^{86}$ Posiedzenie Komisji Oceny Przedsięwzięć Inwestycyjnych (KOPI) z dn. 28 czerwca 2006 r., za: materiały udostępnione przez Biuro Senatorskie Senatora RP Andrzeja Owczarka.

87 Założenia do koncepcji funkcjonalno-przestrzennej lotniska Łask, projekt multimodalny lotniska Łask, "Lotnisko Łask" Sp. z o.o., Łódź, styczeń 2008, s. 3.

${ }^{88}$ NATO Security Investment Programme (NSIP) - Program Inwestycji Organizacji Traktatu Północnoatlantyckiego w Dziedzinie Bezpieczeństwa, w ramach którego jednostki sektora publicznego otrzymuja dotacje celowe na realizacje inwestycji związanych z zapewnieniem bezpieczeństwa narodowego, za: www.rp.pl/artykul/130928.html [z dn. 7.05.2009]. 
ckiego ${ }^{89}$, który przeznacza uzyskane środki pieniężne na realizację zadań publicznych w zakresie inwestycji obronnych, takich jak lotniska, a w szczególności na przebudowę i modernizację obiektów i infrastruktury technicznej znajdującej się $\mathrm{w}$ ich obrębie. Po kilku latach restrukturyzacji, ściśle związanej z przyjęciem do użytkowania i eksploatacji samolotów wielozadaniowych F-16, dnia 1 stycznia 2001 r. powstała 32 Baza Lotnicza90, której trzon stanowiło dowództwo i kadra 10. Pułku Myśliwskiego. Dużym sukcesem okazało się przystosowanie całej infrastruktury lotniska do potrzeb i wymogów NATO. Potrzeba było wiele sił i nakładów pieniężnych, aby powstał kompleks lotniskowy na miarę XXI w. Przez kilka lat inwestowano ogromne środki pozyskane w ramach funduszu Zakładu Inwestycji Organizacji Traktatu Północnoatlantyckiego. Utworzenie nowoczesnego zaplecza dla kompleksu lotniskowego to inwestycja w bezpieczeństwo narodowe. Budynki i urządzenia, czyli to, co stanowi infrastrukturę techniczną lotniska, ma określone parametry. Są to nowoczesne schronohangary, wojskowy port lotniczy oraz różnego rodzaju i przeznaczenia magazyny. W ramach modernizacji oddano do użytku nową Strażnicę Pożarowa, służaca $w$ razie potrzeby nie tylko wojsku, ale i ludności cywilnej. Jednym z ważniejszych posunięć była modernizacja pasa startowego i budowa nowoczesnych systemów poprawiających bezpieczeństwo lotów (system ILS) ${ }^{91}$.

Kolejną ważną datą w historii bazy lotniczej jest 1 stycznia 2010 r., kiedy to na mocy decyzji MON istniejaca 32 Baza Lotnicza oraz 10. Eskadra Lotnictwa Taktycznego utworzyła w drodze przeformowania 32 Bazę Lotnictwa Taktycznego ${ }^{92}$. Obecnie posiada ona na wyposażeniu samoloty wielozadaniowe F-16, czyli jedne z najnowocześniejszych samolotów tego typu na świecie.

${ }^{89}$ Zakład Inwestycji Organizacji Traktatu Północnoatlantyckiego (ZIOTP) - to instytucja gospodarki budżetowej (KRS nr 0000370758), realizująca wymóg Komitetu Infrastruktury NATO dotyczący konsolidacji zadań merytorycznych i finansowo-rozliczeniowych NSIP w jednej instytucji. Podstawowym zadaniem ZIOTP jest realizacja projektów inwestycyjnych z zakresu obronności i bezpieczeństwa, za: www.ziotp.wp.mil.pl [z dn. 13.11.2011].

${ }^{90}$ www.lask.pl/gosp_lotnisko.php [z dn. 16.10.2009].

${ }^{91}$ System ILS (ang. Instrument Landing System) to naziemny radiowy system ladowania, służący podniesieniu bezpieczeństwa lotów podczas niekorzystnych warunków atmosferycznych, za: http://pl.wikipedia.org/wiki/Instrument_Landing_System [z dn. 26.11.2011].

${ }^{92}$ www.32blot.wp.mil.pl/pl/101_456.html [z dn. 15.11.2011]. 
Piloci stacjonujacy w bazie to kwiat polskiego lotnictwa. Kwalifikacje zdobywali na kilkuletnich szkoleniach poza naszym krajem. Swoje umiejętności i doświadczenie moga szlifować w nowoczesnym symulatorze lotów, który został zbudowany przy wydatnej pomocy amerykańskich specjalistów na lotnisku $w$ Łasku93.

Jak można dowiedzieć się z wykładu ówczesnego ministra obrony narodowej Bogdana Klicha, wygłoszonego w Akademii Obrony Narodowej: „transformacja Sił Powietrznych [...] ma na celu poprawę ich zdolności do wykonywania misji bojowych oraz wsparcia transportu lotniczego w ramach narodowych i wielonarodowych połączonych sił zadaniowych NATO i UE"94. Uzmysławia to rodzaj i profil zadań narzucony dla lotnisk wojskowych, na których stacjonujące eskadry lotnicze włączone sa w system zabezpieczenia bojowego. Nasuwa się pytanie: jak zatem połaczyć wojskowe priorytety z zadaniami realizowanymi przez cywilny port lotniczy i terminal cargo?

Jak wynika z projektu opracowanego przez Spółkę "Lotnisko Łask" pod nazwą Koncepcja dostosowania lotniska wojskowego w Łasku do wymogów lotniska cywilnego, sporządzonego w marcu 2006 r., podstawowymi obiektami znajdujacymi się w kompleksie lotniskowym typu cargo będą magazyny, chłodnie, pakowalnie towarów i stanowiska dystrybucji. Na rys. 2 umieszczono slajd z prezentacji multimedialnej przygotowanej przez Spółkę "Lotnisko Łask", na którym przedstawiony jest przykładowy automatyczny magazyn wysokiego składowania. Automatyzacja systemów magazynowania pozwala na śledzenie statusu przesyłek, rejestrację czasu składowania towarów czy też odpowiednie zaplanowanie kompletowania dostaw ${ }^{95}$.

Jako obiekty towarzyszące przewidziano siedziby firm ubezpieczeniowych, banków, różnego rodzaju warsztaty naprawcze oraz stacje benzynowe. Planuje się również wybudowanie hoteli i obiektów wypoczynkowych.

Jedną z wiodących funkcji lotniska cargo miałaby być obsługa spedycji międzynarodowej. W związku z tym przewidziano budowę stanowisk celnych. Swoje miejsce znajda tu również hurtownie i sklepy wolnocłowe. Istniejąca bocznica kolejowa, funkcjonująca obecnie na

${ }^{93}$ www.32blot.wp.mil.pl/pl/67.html [z dn. 16.10.2009].

${ }^{94}$ Reforma systemu dowodzenia i struktur Sit Zbrojnych RP w latach 2009-2018, wykład ministra obrony narodowej w Akademii Obrony Narodowej, 16 stycznia 2009 r., za: http://lotniczapolska.pl [z dn. 19.01.2009].

95 Opracowanie własne na podstawie www.lodz-sitk.org.pl/news/pliki/IV-20kompleks \%20logistyczny\%20Lask.pdf [z dn. 16.09.2009]. 


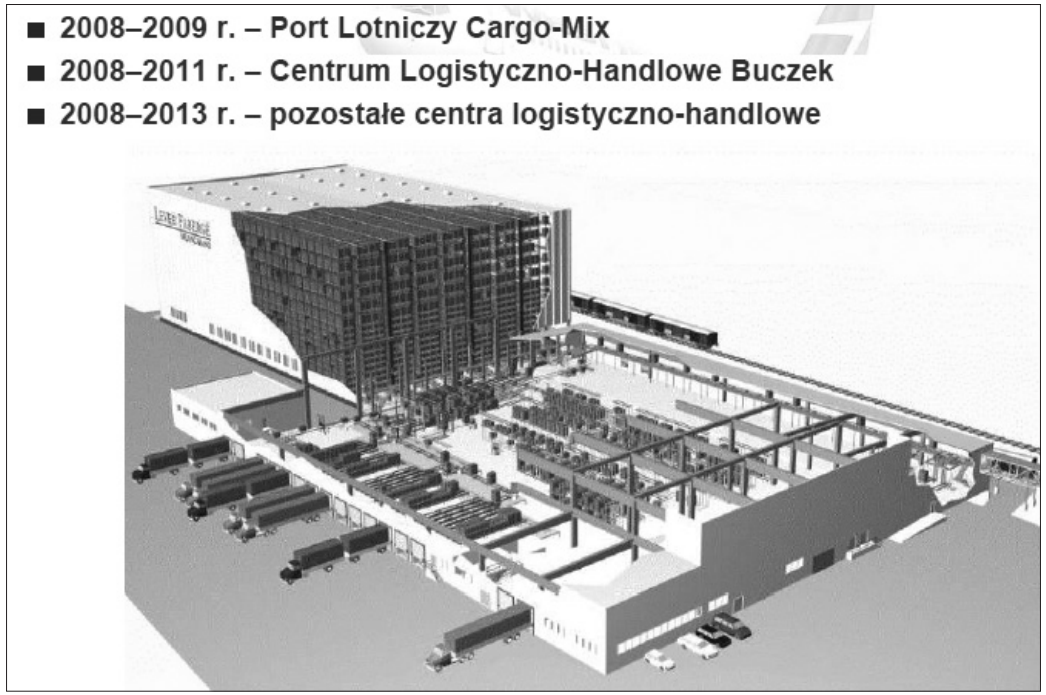

Rysunek 2. Terminy realizacji portu lotniczego cargo Źródło: materiały promocyjne "Lotnisko Łask" Sp. z o.o., Łódź 2006

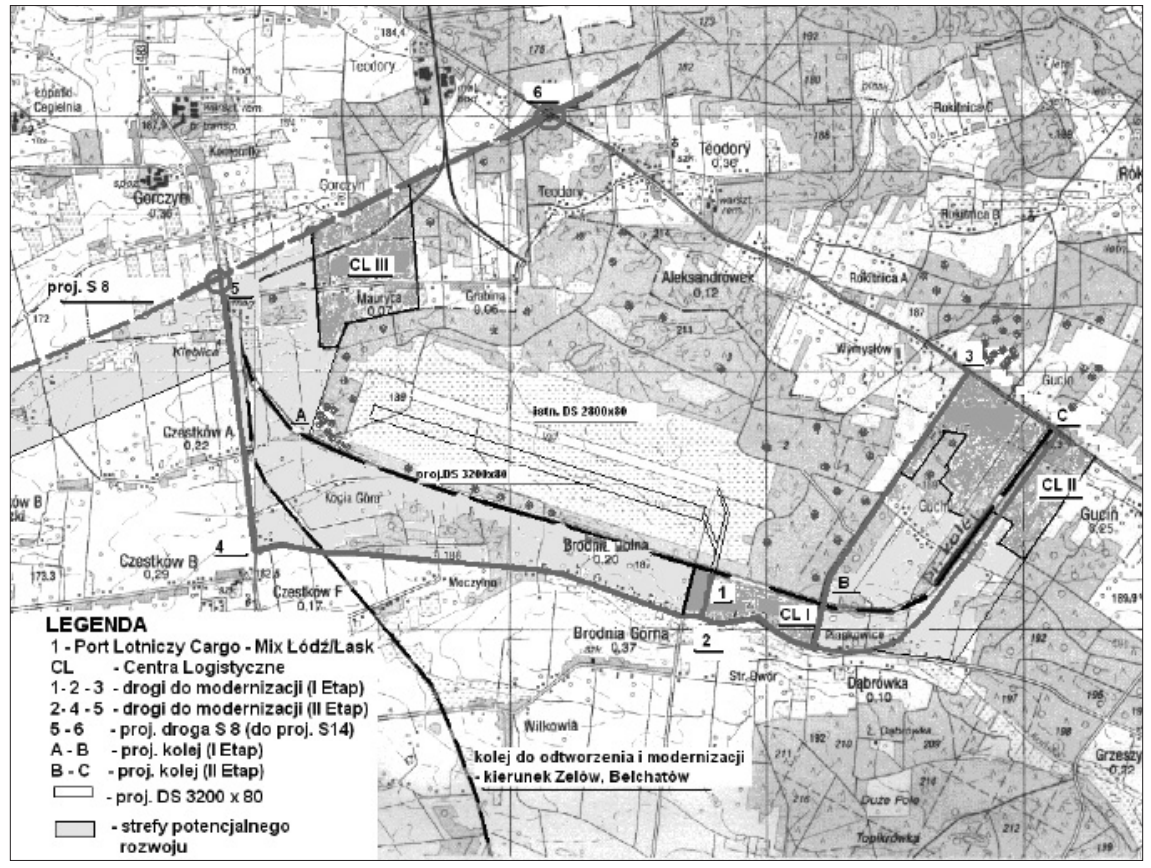

Mapa 8. Lokalizacja projektu lotniska Łask

Źródło: Założenia do koncepcji funkcjonalno-przestrzennej lotniska Łask, projekt multimodalny lotniska Łask, "Lotnisko Łask" Sp. z o.o., Łódź, styczeń 2008, s. 9 
potrzeby kompleksu lotniskowego, mogłaby stanowić dodatkowe połaczenie infrastrukturalne. Zakładano również komunikację powietrzną helikopterową między poszczególnymi centrami logistycznymi.

Tak ogromna inwestycja w pierwszym okresie potrzebować będzie wielkich nakładów finansowych. Przewidziano wydatek rzędu 450 mln euro, z czego 150 mln euro ma kosztować kompleks logistyczny, czyli niezbędna infrastruktura centrum logistyczno-rozładunkowego ${ }^{96}$. Pozostała kwota stanowi wartość połączeń drogowych i szybkiej kolei (tab. 4). Jak widać, sa to ogromne kwoty i imponujący projekt. Zestawienie $w$ tab. 5 ukazuje harmonogram wydatków $w$ rozbiciu na poszczególne elementy zadań do realizacji.

Rozmieszczenie wszystkich obiektów przewiduje się na przestrzeni 750 ha powierzchni gruntów ${ }^{97}$. Jest to olbrzymi teren, który trzeba odpowiednio dostosować, przygotować i uzbroić w różnego rodzaju przyłącza zewnętrzne. Sa to inwestycje praco- i czasochłonne ściśle związane z planem zagospodarowania przestrzennego, który dla miejscowości Łask jest opracowany tylko we fragmentach ${ }^{98}$. Dla terenu, na

${ }^{96}$ Założenia do koncepcji funkcjonalno-przestrzennej lotniska Łask, s. 2.

${ }_{97}$ www. lodz-sitk.org.pl/news/pliki/IV-20kompleks\%20logistyczny\%20Lask.pdf [z dn. 16.10.2009].

${ }_{98}$ Obecnie obowiązuje kilka planów zagospodarowania przestrzennego dla gminy Łask. Są to:

- zmiana miejscowego planu zagospodarowania przestrzennego miasta Łask dla fragmentu obszaru zabudowy mieszkaniowo-usługowej Osiedla Przylesie w rejonie ul. Jodłowej na południe od istniejącej szkoły podstawowej (uchwała nr XXVI/364/97 Rady Miejskiej w Łasku z dn. 8 października 1997 r., Dz. Urz. Woj. Sieradzkiego nr 22, poz. 74 z dn. 08 grudnia 1997 r.),

- zmiana miejscowego planu zagospodarowania przestrzennego miasta Łask dla obszaru w rejonie skrzyżowania ulic Żeromskiego i Lutomierskiej (uchwała nr III/7/98 Rady Miejskiej w Łasku z dn. 27 listopada 1998 r., Dz. Urz. Woj. Sieradzkiego nr 33, poz. 202 $z$ dn. 22 grudnia 1998 r.),

- zmiana miejscowego planu zagospodarowania przestrzennego gminy Łask dla obszaru cmentarza parafialnego w Łasku-Kolumnie przy ul. Torowej (uchwała nr IX/137/03 Rady Miejskiej w Łasku z dn. 10 września 2003 r.),

- zmiana miejscowego planu zagospodarowania przestrzennego miasta i gminy Łask dla obszaru w Łasku-Kolumnie (uchwała nr IX/138/03 Rady Miejskiej w Łasku z dn. 10 września 2003 r.),

- zmiana miejscowego planu zagospodarowania przestrzennego miasta i gminy Łask dla obszaru w Łasku, Łasku-Kolumnie i wsi Ostrów (uchwała nr V/53/03 Rady Miejskiej w Łasku z dn. 26 marca 2003 r., Dz. Urz. Woj. Łódzkiego nr 122, poz. 1229 z dn. 14 maja 2003 r.),

- miejscowy plan zagospodarowania przestrzennego miasta i gminy Łask dla obszarów położonych w Łasku oraz we wsiach Wola Łaska i Ostrów (uchwała nr XVIII/274/04 Rady Miejskiej w Łasku z dn. 15 września 2004 r.). 
Tabela 4. Planowane, lecz niezrealizowane nakłady i horyzonty czasowe realizacji zadań

\begin{tabular}{|l|c|c|}
\hline \multicolumn{1}{|c|}{ Wyszczególnienie } & Nakłady (mln euro) & Lata realizacji \\
\hline Port Lotniczy Cargo-Mix Łódź/Łask & 50 & $2008-2009$ \\
\hline Centrum Logistyczne Lodź/Buczek & 38 & $2008-2011$ \\
\hline Centrum Logistyczne Łódź/Gucin & 150 & $2008-2011$ \\
\hline Centrum Logistyczne Łódź/Gucin & 112,5 & $2011-2013$ \\
\hline Infrastruktura transportowa & 49,5 & $2008-2011$ \\
\hline Droga startowa nowa & 50 & $2010-2011$ \\
\hline Ogółem & 450 & - \\
\hline
\end{tabular}

Źródło: opracowanie - Anna Zmysłowska, na podstawie Założeń do koncepcji funkcjonalno-przestrzennej lotniska Łask, projekt multimodalny lotniska Łask, "Lotnisko Łask" Sp. z o.o., Łódź, styczeń 2008.

którym obecnie znajduje się lotnisko wojskowe, nie ma jak do tej pory żadnych uregulowań tego rodzaju. Tak więc przygotowanie na gruncie formalno-prawnym już na samym poczatku niedomaga. Z punktu widzenia długoterminowych prognoz rozwojowych na następne lata dla regionu środkowej Polski, które przewiduja tu duży postęp i rozwój, warto zainwestować wszystkie dostępne środki pieniężne, aby ta inwestycja miała szanse powstać. Będzie to korzystne nie tylko dla najbliższego otoczenia, lecz także dla całego kraju. W dokumencie planistycznym dotyczącym terenu gminy Łask, noszącym nazwę Zmiana "Studium uwarunkowań i kierunków zagospodarowania przestrzennego miasta i gminy Łask" można przeczytać, że „przekształcenie istniejacego lotniska wojskowego w cywilno-towarowe cargo uznano za jeden z najważniejszych impulsów rozwoju. Skutki tak potężnego stymulatora rozwoju gospodarczego tej części województwa trudno dzisiaj określić. Powinno powstać całe zaplecze obsługi pasażerskiej i towarowej na tym samym lotnisku i w jego pobliżu. W gminie Łask, w sąsiedztwie lotniska już obecnie rezerwowane są duże tereny pod działalność produkcyjno-usługowa" ${ }^{\prime 99}$.

${ }^{99}$ Zmiana "Studium uwarunkowań i kierunków zagospodarowania przestrzennego miasta i gminy Łask", za: uchwała nr XVIII/137/08 Rady Miejskiej w Łasku z dn. 6 lutego 2008 r. w sprawie uchwalenia zmiany "Studium uwarunkowań i kierunków zagospodarowania przestrzennego miasta i gminy Łask". 
Tabela 5. Harmonogram rzeczowo-finansowy

\begin{tabular}{|c|c|c|c|c|c|c|c|c|c|}
\hline Lp. & $\begin{array}{c}\text { Etapy } \\
\text { realizacji }\end{array}$ & Nazwa zadania & 2008 & 2009 & 2010 & 2011 & 2012 & 2013 & Ogółem \\
\hline 1. & \multirow{3}{*}{ I } & Lotnisko Cargo-Mix Łódź/Łask & 10,0 & 40,0 & - & - & - & - & 50,0 \\
\hline 2. & & CL Łódź/Buczek & 8,0 & 8,5 & 10,0 & 11,5 & - & - & 38,0 \\
\hline 3. & & CL Łódź/Gucin & 5 & 50,0 & 50,0 & 45,0 & - & - & 150,0 \\
\hline 4. & III & CL Łódź/Łask & - & - & - & 5,5 & 47 & 60 & 112,5 \\
\hline 5. & \multirow{3}{*}{ II } & $\begin{array}{l}\text { Drogi } \\
\text { 5.1. Modernizacja dróg istniejących } \\
\text { 5.2. Lotnisko S8-S14 }\end{array}$ & 1,5 & $\begin{array}{l}2,3 \\
1,0\end{array}$ & $\overline{5,0}$ & $\overline{6,0}$ & - & - & $\begin{array}{r}3,8 \\
12,0\end{array}$ \\
\hline 6. & & \begin{tabular}{|l} 
Kolej \\
6.1. Bocznica kolejowa CLŁ/Brodnica \\
6.2. Bocznica kolejowa Gucin \\
6.3. Modernizacja węzłów kolejo- \\
wych: Łask, Łask Kolumna \\
6.4. Modernizacja kolei dla potrzeb \\
Cargo \\
6.5. Odtworzenie i modernizacja linii \\
kolejowej Łask-Zelów
\end{tabular} & $\begin{array}{l}- \\
- \\
- \\
- \\
2,0\end{array}$ & $\begin{array}{c}2,5 \\
- \\
1,0 \\
1,5 \\
5,5\end{array}$ & $\begin{array}{l}- \\
2,0 \\
1,2 \\
1,6 \\
0,9\end{array}$ & $\begin{array}{l}- \\
- \\
- \\
2,5 \\
-\end{array}$ & $\begin{array}{l}- \\
- \\
- \\
- \\
-\end{array}$ & $\begin{array}{l}- \\
- \\
- \\
- \\
-\end{array}$ & 20,7 \\
\hline 7. & & $\begin{array}{l}\text { Komunikacja lotniska z centrami } \\
\text { logistycznymi } \\
\text { 7.1. Powietrzna } \\
\text { 7.2. Drogowa } \\
\text { 7.3. Torowa - szybki tramwaj }\end{array}$ & $\begin{array}{l}- \\
5,0 \\
-\end{array}$ & $\begin{array}{l}0,5 \\
- \\
2,0\end{array}$ & $\begin{array}{l}- \\
- \\
5,5\end{array}$ & $\begin{array}{l}- \\
-\end{array}$ & $\begin{array}{l}- \\
-\end{array}$ & $\begin{array}{l}- \\
- \\
-\end{array}$ & 13,0 \\
\hline 8. & III & 8. Droga startowa nowa & - & - & 25,0 & 25,0 & - & - & 50,0 \\
\hline & & Ogółem & 31,5 & 114,8 & 76,2 & 70,5 & 47 & 60 & 450 \\
\hline
\end{tabular}

Źródło: Założenia do koncepcji funkcjonalno-przestrzennej lotniska Łask, projekt multimodalny lotniska Łask, "Lotnisko Łask" Sp. z o.o., Łódź, styczeń 2008, za: materiały udostępnione podczas spotkania z prezesem Zbigniewem Tynenskim, Łódź, 12 listopada $2011 \mathrm{r}$.

Prace legislacyjne, jak powszechnie wiadomo, niezależnie od szczebla terytorialnego zawsze przeciągaja się w czasie. Należy niezwłocznie przystapić do sporządzenia planu zagospodarowania, który uporządkuje całą sytuację prawną na danym terytorium i sprawi, że wszelkie inwestycje otrzymaja niezbędne zgody i pozwolenia w zdecydowanie krótszym czasie, co będzie miało ogromny wpływ na wysokość poniesionych kosztów i zmniejszenie ilości zbędnej niekiedy dokumentacji.

Kolejnym zagrożeniem dla powstania lotniska cargo jest nie do końca uregulowana sytuacja prawna terenów pod budowę istniejącego wojskowego lotniska. Okoliczni mieszkańcy w latach 50. ubiegłego wieku oddawali swoja ziemię niejako w poczuciu dobrze wypełnionego obywatelskiego obowiązku. Obawy senatora Andrzeja Owczarka co 
do koniecznych zmian w prawie pozwalającym wykorzystywać wojskowe bazy sa w pełni uzasadnione ${ }^{100}$. W takiej sytuacji, gdy istniejące lotnisko nabrałoby charakteru komercyjnego, niejeden mieszkaniec ziemi łaskiej mógłby upomnieć się o swoją ojcowiznę. Oczywiście w dobie istnienia specustawy i te bariery sa do pokonania ${ }^{101}$.

Cały ciężar opracowania, stworzenia dokumentacji i realizacji przedsięwzięcia wzięła na siebie Spółka "Lotnisko Łask". Została ona zawiązana w 1999 r. Jej głównymi udziałowcami zostali:

- Skarb Państwa,

- Fundacja na Rzecz Restrukturyzacji Regionu Łódzkiego,

- Gmina Łask,

- Gmina Buczek,

- Powiat Łaski,

- Miasto Zelów,

- Gmina Dobroń,

- Centrum Zrównoważonego Rozwoju,

- MESAGO Holding GmbH Stuttgart.

23 czerwca 2005 r. obradujace Walne Zgromadzenie Wspólników wybrało na prezesa spółki inż. Zbigniewa Tynenskiego. Siedziba spółki mieści się $w$ Łodzi przy ul. Legionów 2.

W latach 2006-2008 na drodze uzgodnień ze stroną wojskową stworzono kilka dokumentów planistycznych, w których umiejscowiono terminal cargo poza obecnym terenem kompleksu lotniczego. Między innymi opracowano dokument Koncepcja dostosowania lotniska wojskowego $w$ Łasku do wymogów lotniska cywilnego. Precyzował on na drodze uzgodnień obu zainteresowanych stron lokalizację przyszłego lotniska cywilnego i terminalu cargo wchodzącego w jego skład. Uzgodnienia prowadzone były w Sztabie Generalnym Dowództwa Sił Powietrznych w Warszawie, gdzie koncepcja ta uzyskała opinię pozytywna dla przedmiotowego projektu. Jak wynika z pisma wychodzącego nr 207/07 z 31 stycznia 2007 r., będącego odpowiedzią Dowództwa Sił Powietrznych w osobie dowódcy, gen. broni pilota Stanisława Targosza, strona wojskowa od początku była zainteresowana współpracą ze strona cywilną. W treści pisma czytamy: "W odpowiedzi na pismo [...] pragnę poinformować Pana Burmistrza, że pozytywnie oceniam

100 Opracowanie na podstawie wydania internetowego "Gazety Wyborczej", 7.04.2008.

101 Ustawa z dnia 10 kwietnia 2003 r. o szczególnych zasadach przygotowania i realizacji inwestycji w zakresie dróg publicznych, Dz.U. z 2006 r., nr 80, poz. 721. 
projekt współużytkowania lotniska wojskowego w Łasku przez podmiot cywilny"102.

Jak widać, strona wojskowa dawała pozytywne przesłanki dla realizacji lotniska cargo. Wojsko ma świadomość, że dwa współpracujace podmioty na jednym terenie lotniskowym z punktu widzenia bezpieczeństwa lotów mają większą szansę nadzoru ich przebiegu - jeden teren monitorowany jest w dwójnasób, co poprawia sprawność i skuteczność działań różnych służb lotniskowych.

Postępem budowy tej inwestycji i rozległa współpraca biznesowa zainteresowanych było około 30 podmiotów obecnie działających w Łódzkiej Specjalnej Strefie Ekonomicznej. Przyszłym lotniskiem cargo zaczęły interesować się również podmioty zagraniczne. Chęć współpracy wyraziły Kanadyjskie Linie Lotnicze, które lotnisko cargo w Łasku traktowałyby jako międzylądowanie na linii Kanada-Pakistan. Współdziałanie deklarowały również władze Walonii, która jest centrum kulturowym i ekonomicznym wschodniej Belgii. Port Lotniczy Liège, położony $9 \mathrm{~km}$ od miejscowości Liège, jest obecnie drugim portem cargo pod względem ilości towarów i możliwości przeładunkowych w Belgii. Przedstawiciele istniejącego tam lotniska zainteresowani byli współpraca z przyszłym lotniskiem cargo $\mathrm{w}$ Łasku. Oba terminale otrzymałyby status lotnisk partnerskich, dzięki czemu mogłyby realizować zadania europejskiego transportu cargo.

W październiku 2007 r. Spółka "Lotnisko Łask" opracowała kolejny dokument planistyczny dotyczący inwestycji cargo. Nosił on tytuł Planowane zadania inwestycyjne kompleksu logistycznego Łódź/Łask. Jak wynika z korespondencji wystosowanej do prezesa Zbigniewa Tynenskiego przez sekretarza stanu Marka Zajakały z Ministerstwa Obrony Narodowej, resort wojskowy "przedstawiona inicjatywę [...] przyjmuje ze zrozumieniem i podtrzymuje gotowość do podjęcia współpracy w tym zakresie. [...] pragnę wyrazić nadzieję, że stanowisko resortu obrony narodowej w przedmiotowej sprawie pozwoli na kontynuowanie podjętych działań i przyczyni się do współpracy cywilno-wojskowej na lotnisku w Łasku w sposób satysfakcjonujący obie strony"103.

102 Pismo nr 207/07 z dn. 31 stycznia 2007 r. Dowódcy Sił Powietrznych gen. broni pilota Stanisława Targosza do burmistrza Łasku Gabriela Szkudlarka w sprawie współużytkowania lotniska Łask przez stronę cywilna, za: materiały udostępnione podczas spotkania z prezesem Zbigniewem Tynenskim, Łódź, 12 listopada 2011 r.

103 Pismo nr 1668/DI z dn. 28 maja 2007 r. sekretarza stanu MON Marka Zajakały do prezesa Spółki "Lotnisko Łask" Zbigniewa Tynenskiego dotyczące współpracy ze stroną cywilna, za: materiały udostępnione przez Biuro Senatorskie Senatora RP Andrzeja Owczarka. 
Za powstaniem inwestycji o tak ważnym charakterze lobbowało wielu znamienitych przedstawicieli życia politycznego. Wielkim zwolennikiem powstania lotniska cargo był prezydent Łodzi Jerzy Kropiwnicki. To za jego kadencji omawiane przedsięwzięcie miało największe szanse na realizację. Obecnie urzędujący wojewoda łódzki Jolanta Chełmińska bardzo popiera wszelkie działania związane z tą inwestycją. Jednak nie przynosza one pożądanego efektu i trafiaja w pustkę. Urząd Wojewody jest jak najbardziej powołany kompetencyjnie do stanowienia decyzji na terenie zamkniętym. Reguluje to ustawa o zagospodarowaniu przestrzennym, która mówi, że: „decyzje o warunkach zabudowy na terenach zamkniętych wydaje wojewoda"104. Wiele wysiłku na rzecz powstania lotniska cargo wkłada również doradca wojewody łódzkiego Andrzej Cymerman. Będąc dyrektorem Biura do spraw Autostrad w Urzędzie Wojewódzkim oraz ekspertem w dziedzinie infrastruktury, jest szczególnie zainteresowany powodzeniem przedmiotowego przedsięwzięcia.

W świetle przytoczonych faktów tym bardziej dziwi postawa władz samorządowych gminy Łask. Na XV posiedzeniu Rady Miejskiej w Łasku, które odbyło się w sali konferencyjnej Starostwa Łaskiego, 26 października 2011 r. podjęto decyzję o odsprzedaży udziałów, którymi dysponuje Gmina Łask i wystapieniu z grona udziałowców Spółki "Lotnisko Łask". Jak można dowiedzieć się ze stenogramu posiedzenia, radni zdecydowali o wystapieniu Gminy Łask ze Spółki "Lotnisko Łask" i wyrazili zgodę na zbycie udziałów tej spółki. Wywiad przeprowadzony przez reportera lokalnej Telewizji Centrum ujawnia uzasadnienie tej niefrasobliwej decyzji: „Dalsze istnienie Spółki «Łask cargo», wiedząc, że na loty cywilne nie ma szans, jest bezsensowne. Obawiam się, że [...] trudno będzie nam zbyć te akcje, bo jakiś czas temu minister Skarbu Państwa zwrócił się do nas, bo Skarb Państwa też w tym partycypował, no i nie było nikogo chętnego. [...] Cieszymy się z tego, co mamy, a dalsze utrzymywanie takiej spółki to fikcja - powinna być wykreślona z rejestru spółek"105.

Sytuacja spółki, przed którą stała świetlana przyszłość, a przedmiot realizacji należał do priorytetów inwestycyjnych województwa łódzkiego, nie należy do komfortowych. Prezes Tynenski nosi się z zamiarem zawieszenia działalności gospodarczej. Jednak pojawiające się prze-

104 Ustawa z dn. 27 marca 2003 r. o planowaniu i zagospodarowaniu przestrzennym, rozdział 5 , art. 60 , pkt. 3 .

105 Wywiad przeprowadzony w dn. 26 października 2011 r. z burmistrzem Łasku Gabrielem Szkudlarkiem, za: www.telewizjacentrum.pl [z dn. 13.11.2011]. 
słanki, które omawiane były ze Spółką "Lotnisko Łask" niosa pewną dozę optymizmu ${ }^{106} \mathrm{w}$ tej materii. Jeszcze nie należy składać broni, być może pewnego dnia nastapi przełom i powrót do koncepcji istnienia towarowego lotniska w Łasku.

${ }^{106}$ Informacja dotycząca zaistniałej sytuacji jest poufna. Z uwagi na ten fakt nie można przytoczyć informacji, jakie uzyskano na spotkaniu w dniu 12 listopada 2011 r. w siedzibie spółki w Łodzi. 